\title{
Analyzing the effect of silvicultural management on the trade-off between stand structural heterogeneity and productivity over time
}

\author{
Laura Zeller $^{1}$ D $\cdot$ Astor Toraño Caicoya ${ }^{1} \cdot$ Hans Pretzsch $^{1}$
}

Received: 9 January 2020 / Revised: 12 August 2020 / Accepted: 19 December 2020 / Published online: 1 February 2021

(c) The Author(s) 2021

\begin{abstract}
This study combined an empirically based simulation with an analysis of the trade-off between structural heterogeneity and stand productivity depending on time, spatial scale, and silvicultural management, whereas volume growth and tree species diversity have been examined in detail, the role of forest structure and its interdependencies with stand productivity has only lately become a stronger research focus. We used the growth simulator SILVA to examine the development of stand structural heterogeneity and its trade-off with stand productivity in age-class versus uneven-aged pure and mixed spruce and beech stands at different spatial scales over 100 years. Those stands were based on typical forest types in Bavaria and were representative of forests in Central Europe. We examined how stand structure and its trade-off with productivity were modified by a multifunctional, a production-oriented, and a set-aside management scenario. The production-oriented management scenario applied to uneven-aged stands led to a reduction in structural heterogeneity per unit of productivity over time. In age-class stands, the production-oriented scenario was able to maintain the initial structural heterogeneity. The structural heterogeneity per unit of productivity increased more strongly with increasing spatial scale in age-class stands compared to uneven-aged stands. Combining forest stand simulation with scenario analyses is an exemplary method for testing the effect of silvicultural management alternatives on forest structure. This approach can later be connected to climate models considering long-term changes in growing conditions and support the planning of multifunctional forests.
\end{abstract}

Keywords Forest ecosystem functions and services $\cdot$ Forest stand growth $\cdot$ Management scenarios $\cdot$ Multifunctionality Structural complexity $\cdot$ Virtual forest

\section{Introduction}

Sustainably maintaining multifunctional forest ecosystems has become a widespread objective of forest management (Manning et al. 2018; Schmithüsen 2008). This development increases the interest in analyzing the potentially strong influence of tree species diversity (Paquette and

Communicated by Peter Biber.

Laura Zeller

laura.zeller@tum.de

Astor Toraño Caicoya

astor.torano-caicoya@tum.de

Hans Pretzsch

hans.pretzsch@tum.de

1 Chair of Forest Growth and Yield Science, School of Life Sciences Weihenstephan, Technical University of Munich, Hans-Carl-von-Carlowitz-Platz 2, 85354 Freising, Germany
Messier 2011; Gamfeldt et al. 2013; Liang et al. 2016) and forest structure on ecosystem functions and services (FelipeLucia et al. 2018; Bohn et al. 2018; Bohn and Huth 2017). Previously established monospecific and even-aged forests had the aim of a high yield and the homogeneous provision of a narrow range of predominant products, which were produced with the aim to provide a homogeneous product quality (Puettmann et al. 2015). Silvicultural management has shifted its focus to multifunctional mixed forests (Salek and Sivacioğlu 2018). Here, stand structural heterogeneity emerges as an important factor when the aim of management is to provide a broad range of forest ecosystem functions and services (Felipe-Lucia et al. 2018). Different studies show positive (Danescu et al. 2016), but often negative (Soares et al. 2016; Bourdier et al. 2016) effects of stand structural heterogeneity on wood production. The potential negative effect of structural heterogeneity on wood production is balanced by a broad range of beneficial effects on habitat heterogeneity (Ghadiri Khanaposhtani et al. 2012), biodiversity 
(Lindenmayer et al. 2000; Tews et al. 2004), carbon storage (Ali et al. 2016), mechanical stability (Mason 2002; Gardiner et al. 2005), and resilience (O'Hara and Ramage 2013). When aiming at a high biodiversity, certain stand structural characteristics are particularly important as they help to create the needed habitats (Enquist et al. 2009). Tree size heterogeneity fosters bird habitats and the diversity of birds (MacArthur and MacArthur 1961) and different plant species (Gärtner and Reif 2004). Old and large trees can serve as retention trees and can be important for many bird species (Lutz et al. 2013) and general habitat diversity (Ranius et al. 2005; Gustafsson et al. 2012; Fedrowitz et al. 2014; Sefidi 2018 ) resulting in a higher biodiversity (Nascimbene et al. 2009; Fedrowitz et al. 2014).

Crown cover is important for birds (Heikkinen et al. 2004), insects (Franc et al. 2007), and different plant species (Benítez et al. 2015). Further, the number of occupied forest layers is vital for birds (Tews et al. 2004), different plants (Mestre et al. 2017), and biodiversity in general (Mensah et al. 2018).

Stand structural heterogeneity is commonly quantified using indices based on tree size distribution (Pommerening 2002; Bohn and Huth 2017). These indices are easily calculated also by forest practitioners and based on data that is usually sampled in forest inventories (Sabatini et al. 2015; Fischer and Mölder 2017).

High structural heterogeneity originates partly from tree species mixing due to the differences in growth rates and requirements among tree species (del Río et al. 2015). In Germany, Norway spruce (Picea abies (L.) H. Karst.) and European beech (Fagus sylvatica L.) are the most common coniferous and deciduous tree species, respectively, and together represent about $40 \%$ of the forest area in the country (Bundesministerium für Ernährung und Landwirtschaft BMEL 2014). A shift from Norway spruce and Scots pine (Pinus sylvestris L.) monocultures to mixed continuous cover forests (Puettmann et al. 2015) is intended for many regions in Europe for economic (Pommerening 2006; Knoke 2012), ecological (Nordström et al. 2013), and other reasons (Nordström et al. 2013). The advantages of a transition to species-diverse forests are also being discussed in other parts of Europe (Kuuluvainen et al. 2012; Dieler et al. 2017) and globally (Naeem et al. 2012; Liang et al. 2016).

Even-aged, or age-class stands still exist in Europe but have been increasingly transformed into uneven-aged stands (Sterba and Zingg 2001; Nyland 2003). The chosen initial stand structure and tree species composition therefore represent existing forest types that are of practical concern and part of the current debate on the sustainable and multifunctional management of forests in Europe (Bundesministerium für Ernährung, Landwirtschaft und Verbraucherschutz BMELV 2011; Gustafsson et al. 2012, 2019; Borrass et al. 2017).
While taking into account and incorporating various ecosystem functions and services into the portfolio, forest management often still has to focus on a high wood production due to high demands in wood products in Europe (Buongiorno et al. 2011). Production-oriented forestry is often associated with the above-mentioned age-class stands that automatically have a lower structural heterogeneity than uneven-aged stands. Germany is dominated by high-forests. Two common management approaches in high forest management concerning regeneration, thinning, and harvesting are age-class forest management and continuous cover forestry for uneven-aged stands (Burschel and Huss 2003; Pommerening and Murphy 2004). In the case of age-class forest management, artificial or natural regeneration is applied after harvesting at the end of the rotation period. There are usually only one or two tree layers present. The rotation period is an important determinant of the amount and time of harvesting activities. The selection of tree species is rather focused on fast-growing conifers. Monocultures with one or two layers managed by age-class management are still present but have increasingly been transformed into uneven-aged stands and are now managed under the goal of a continuous cover forest.

In continuous cover forestry, trees of different ages grow next to each other, and selective cutting is applied. Regeneration also happens continuously below and in between older trees. Continuous cover forestry aims to provide continuous crown cover, tree species mixing, and regeneration with deciduous tree species. Continuous cover forestry also results in increased tree size inequality and thus increased structural heterogeneity. An increase in stand structural heterogeneity, however, has in many cases been found to negatively influence stand productivity (Mainwaring and Maguire 2004; Liang et al. 2007; Bourdier et al. 2016), particularly in pure stands (Soares et al. 2016; Zeller et al. 2018). Continuous cover forestry further attempts to integrate multifunctionality into production forests (Schwaiger et al. 2019).

In national parks or other set-aside areas, no commercial management is applied. This hands-off approach can reveal how forests develop without intervention, or after abandonment. Structural heterogeneity can be higher than in production forests and includes an old-growth phase with very old and large trees and parallel regeneration (Simonsson et al. 2016).

To obtain a rough estimate on how silvicultural management influences the structure-productivity relationship in both age-class and uneven-aged pure and mixed stands in the long-term, simulation has been demonstrated to be a useful tool (Laudon et al. 2011; Biber et al. 2015; Schwaiger et al. 2018a). In this study, we generated virtual forest stands consisting of mainly Norway spruce and European beech with different initial stand structures (age-class vs. uneven-aged) 
and spatial arrangements (pure stands, single-tree mixture, and section-wise mixture). The stands were consecutively thinned with a selection thinning between heights of 12 and $32 \mathrm{~m}$ according to different management scenarios.

We applied the three scenarios "production-oriented," "multifunctional," and "set-aside" to the virtual forest stands. The production-oriented scenario focused on thinning from below and shorter rotation periods in coniferdominated stands, compared to the multifunctional scenario. After harvest, the broad-leaved stands were rather replanted with conifers in the production-oriented scenario, whereas the multifunctional scenario intended an increase in the share of oak.

These scenarios represent the common silvicultural management approaches applied in Germany that have resulted in the existing age-class forests, continuous cover forests, and set-aside forests, respectively (Bundesministerium für Ernährung, Landwirtschaft und Verbraucherschutz BMELV 2011). By applying all three scenarios to both initial ageclass and uneven-aged pure and mixed stands, we tested the effects of management on the most common existing types of stand structure. This could either represent a continuing type of management or a sudden shift from one management approach to another, depending on the previous management that has led to the different forest types used as initial stands in this study.

The focus was on quantifying forest structural heterogeneity and putting it in a relation with stand productivity. The negative effect of high structural heterogeneity on the wood production found in some cases (Soares et al. 2016; Zeller et al. 2018) can result in a trade-off between stand structure and productivity (Dieler et al. 2017; Felipe-Lucia et al. 2018). It is of great interest how forest management can modify this conflict of interests since structural heterogeneity is key to many other ecosystem functions and services (Bohn and Huth 2017). In some cases, a high multifunctionality was best predicted by functional heterogeneity, rather than by size diversity (Mensah et al. 2020). Still, structural and functional heterogeneity can be interdependent and stand structure is determined by the functions and traits of the present species. A forest stand can, for example, have multiple layers because of the species' different light requirements. Since the focus of this study was the relative dependency between structural heterogeneity and productivity, quantifying the trade-off by a simple ratio was applicable. The aim of increasing either wood production or sacrificing productivity for a higher structural heterogeneity was incorporated in the management scenarios prioritizing different aims.

The extent of structural heterogeneity in forests moreover depends on the spatial scale at which it is measured (Leimgruber et al. 2002; Stein et al. 2014; Bhakti et al. 2018). Depending on the purpose of a forest, a provision of certain stand characteristics might be sufficient or particularly important at a larger spatial scale (Saab 1999; van der Plas et al. 2016). In some cases, instead of a high structural heterogeneity at the tree level, habitat heterogeneity was found to be particularly important at larger spatial scales for overall biodiversity (Tews et al. 2004; Yang et al. 2015; Schall et al. 2018b). The selected virtual forest stands enabled the comparison between structural heterogeneity at tree level (uneven-aged stands) and stand level (age-class stands).

This study represents an overarching approach complementing existing findings on the effects of forest management (Crow et al. 2002; Pukkala et al. 2011; Dieler et al. 2017) and aims at linking aspects, such as stand structure, productivity, silvicultural management, time, and spatial scale, which are often examined individually (Coll et al. 2018). It addresses the research on forest structure and forest growth as a basis for adjacent research on the multifunctionality of forest ecosystems by examining the following research question:

How do stand structural heterogeneity and productivity in age-class vs. uneven-aged stands develop over time and with spatial scale in different management scenarios?

\section{Materials and methods}

\section{Data and virtual stands}

Virtual stands were formed based on patches of 16 ha (strata) that resulted from a stratification of the German National Forest Inventory. This process was part of the standard simulation process of the forest simulator SILVA (Pretzsch 2001), which was then used to elaborate the scenarios. The individual inventory points for the State of Bavaria were grouped according to structural characteristics (tree size distribution, species composition) and to the ecological region that they represent. The strata were defined by specific structures and average spatial distributions. All data points belonging to each stratum were used to generate a representative stand of a defined area (16 ha) using the STRUGEN algorithm (Pretzsch 2009). During this process, simulated individual trees were iteratively distributed by point process algorithms over the area until the stand structure met the predefined structural parameters. This stratification process ensures that each stratum represented real forests in Bavaria (Bundesministerium für Ernährung und Landwirtschaft BMEL 2014).

We generated eight virtual forest stands that mainly consisted of Norway spruce and European beech in similar shares, according to standing volume; and very low numbers of pine and sessile oak (Quercus petraea (Matt.) Liebl.). The resulting eight different virtual forest stands consisted of 12 strata (each $16 \mathrm{ha}$ ). The resulting total stand size was therefore 12 strata $\times 16$ ha $=192$ ha. One age-class stand and one 
uneven-aged stand of each of the four types of species compositions were set up: pure spruce (Figure A 1 and Figure A 2) pure beech (Figure A 3 and Figure A4), a single-tree mixture of spruce and beech (Figure A5 and Figure A6), and a section-wise mixture that included 1 Sect. (96 ha) of pure spruce and 1 Sect. (96 ha) of pure beech next to each other (Figure A7 and Figure A8). For a comparable starting situation, the selected strata included a similar range of tree sizes (dbh and height distribution), number of trees per ha, and standing volume $\left(\mathrm{m}^{3} \mathrm{ha}^{-1}\right)$ (Table 1, 2). Variation in the spatial allocation of the trees in the stand resulted from the age-class versus uneven-aged stand structure. In the continuous cover stands, the 12 different strata (each 16 ha) had similar diameter distributions with small, medium, and large diameters present. In the age-class stands, the diameters inside the strata were mostly of one age-class and therefore of similar size. At stand level (192 ha), there were consequently different age-classes present.

The number of trees per ha and volume per ha was first calculated for each of the strata to show the variability among the 12 strata inside the 192 ha forest stands (Table 1). All strata forming the 192 ha stands were based on the same soil and growing conditions. Apart from the intended differences in the management and initial structure (age-class vs. uneven-aged), the stands were thus similar.

\section{Growing window for different spatial scales}

For the continuous analysis of structural heterogeneity at different spatial scales, we used a growing window technique (Cyganek 2005). A circle was drawn around each of the 30 random points with increasing radius $\mathrm{k}$ for the radii 5,10 , $25,50,75,100,150,250,500,750,1000$, and $2000 \mathrm{~m}$. The circles thus comprised an increasing area to be examined around each random point of $79 \mathrm{~m}^{2}$ up to the maximum area of the virtual forest stand (192 ha). A radius of $2000 \mathrm{~m}$ represented the diagonal of the stand, ensuring that largest circle around each random point covered the whole stand area, even if the random point was located in a corner of the stand. The area of each circle outside the stand borders was ignored, and mean values were calculated for the overlapping area of each circle with the stand area. One mean value per stand, point in time, and radius were thus retrieved from the growing window analysis and use for the further analyses of this study.

\section{Growth simulation by SILVA}

The growth of the virtually designed forest stands was simulated in 5-year steps over 100 years using the individual tree growth simulator SILVA (Pretzsch 1996). SILVA was developed, and evaluated, and has been successfully applied in forest practice since 1989 by the Chair of Forest Growth

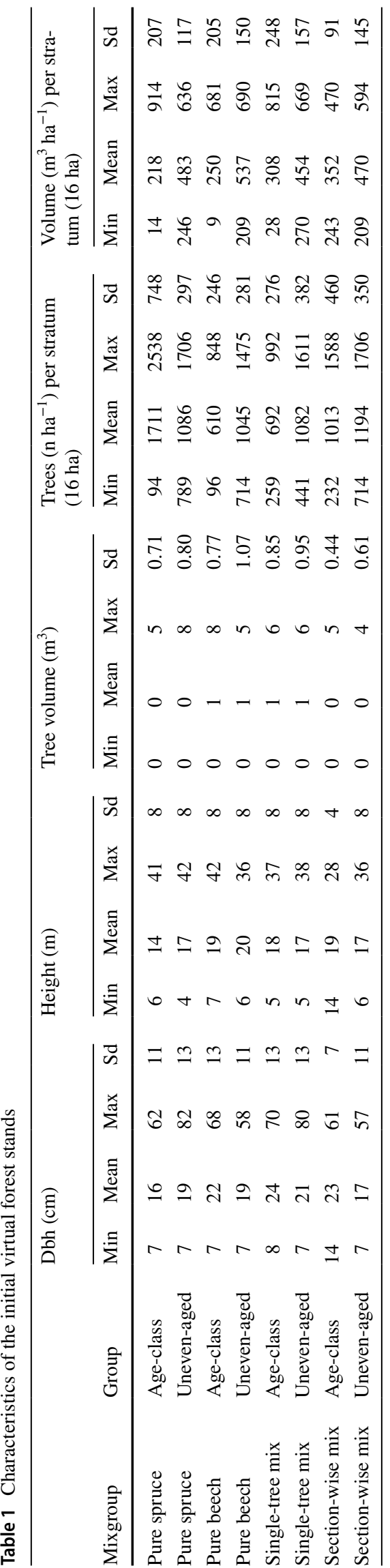


Table 2 Overview of structural indicators applied in this study

\begin{tabular}{|c|c|c|c|}
\hline Code & Name & Equation & Description \\
\hline Dbh.cv & $\begin{array}{l}\text { Coefficient of variation } \\
\text { of dbh }\end{array}$ & $d b h . c v=\frac{s d}{-\overline{-}}$ & $\begin{array}{l}\text { The dbh.cv (Brown 1998) relates the standard deviation } s d \text { to the mean } \overline{d b h} \text {. It } \\
\text { measures tree size heterogeneity within a defined area based on dbh }\end{array}$ \\
\hline SDI & Stand density index & $\mathrm{SDI}=N \cdot\left(\frac{25}{d q}\right)^{-1.605}$ & $\begin{array}{l}\text { The SDI by Reineke (Reineke 1933) uses total stem number per ha, } \mathrm{N}=\sum_{i=1}^{N} n_{i} \text {, } \\
\text { and the quadratic mean diameter dq. SDI enables the comparison of forest } \\
\text { stands of different ages }\end{array}$ \\
\hline Vol & Standing volume & $\mathrm{Vol}=\mathrm{m}^{3} \mathrm{ha}^{-1}$ & The standing volume vol is the quantity of merchantable timber per ha \\
\hline Ivol & Volume increment & Ivol $=\mathrm{m}^{3} \mathrm{ha}^{-1} \mathrm{yr}^{-1}$ & $\begin{array}{l}\text { The ivol quantifies the volume increment in merchantable timer per hectare and } \\
\text { year }\end{array}$ \\
\hline Rel.ivol & $\begin{array}{l}\text { Relative volume incre- } \\
\text { ment }\end{array}$ & Rel.ivol = ivol / vol & $\begin{array}{l}\text { The rel.ivol is the volume increment }\left(\mathrm{m}^{3} \mathrm{ha}^{-1} \mathrm{yr}^{-1}\right) \text { per standing volume vol }\left(\mathrm{m}^{3}\right. \\
\left.\mathrm{ha}^{-1}\right) \text { in } \%\end{array}$ \\
\hline
\end{tabular}

and Yield of the Technical University of Munich. This simulation program is based on empirical data, considers individual tree positions, competition with neighbor trees, and is suitable for forests in Central Europe (Pretzsch 1992; Pretzsch et al. 2006). SILVA enables the testing of the effect of different types of silvicultural practices on forest growth and other ecosystem functions and services (Poschenrieder et al. 2018; Schwaiger et al. 2018a, 2018b).

\section{Management scenarios}

The management scenarios considered in this study comprised a large set of silvicultural practices that represent the current challenges in forest management (Pretzsch et al. 2007). These provide species-specific details for every target tree species modeled in SILVA, which are Norway spruce, Scots pine, silver fir (Abies alba), European larch (Larix decidua), European beech, sessile (Quercus petraea (Matt.) Liebl.) and common oak (Quercus robur), Douglas-fir (Pseudotsuga Menziesii), hardwood deciduous, and softwood deciduous (Pretzsch et al. 2002). Each intervention was defined depending on the dominant species in the stand and was applied specifically to the defined height phases, i.e., stand development stages. In our study, we have not included climate-related changes and have instead set climate as constant to focus purely on the effect of management.

A multifunctional and a production-oriented scenario, respectively, were applied to show the differences in management impact, depending on the different initial structures (age-class vs. uneven-aged stands) in different species compositions (pure spruce, pure beech, single tree mixture spruce-beech, section-wise mixture spruce-beech). For reference, an unmanaged set-aside scenario was used.

The multifunctional scenario (Table A 1 and Fig. 1) integrated ecosystem functions and services into the management of production forests (Bayerische Staatsforsten 2008; Schwaiger et al. 2019) and included the goal of a continuous crown cover, as well as a high structural heterogeneity and species diversity, including a higher share of deciduous species. Depending on the dominant tree species of each stratum, silvicultural treatments were conducted according to Table A 1, column 1. From stand establishment to the stand stage with a dominant height of $12 \mathrm{~m}$, a stem number reduction and a removal of $15 \mathrm{~m}^{3} \mathrm{ha}^{-1}$ of standing volume at maximum per intervention were carried out. Selective thinning was conducted at a dominant height between 12 and $32 \mathrm{~m}$, which removed up to $55 \mathrm{~m}^{3} \mathrm{ha}^{-1}$ of standing volume in deciduous-dominated stands and up to $70 \mathrm{~m}^{3} \mathrm{ha}^{-1}$ in coniferous-dominated stands per intervention. The target diameter harvest phase started at a dominant height of $32 \mathrm{~m}$ and removed between 80 and $144 \mathrm{~m}^{3} \mathrm{ha}^{-1}$ of conifers and 70 $\mathrm{m}^{3} \mathrm{ha}^{-1}$ in deciduous-dominated stands. All the conducted treatments were applied in turns of two simulation periods (10 years) (Toraño Caicoya et al. 2018). In this scenario, natural regeneration was the main contributor to the ingrowth. To improve species diversity, Scots pine (500 trees ha ${ }^{-1}$ ) was planted during the regeneration phase in the coniferdominated stands. In the deciduous-dominated stands, in addition to the natural regeneration, Scots pine (250 trees $\mathrm{ha}^{-1}$ ), European beech (6000 trees ha ${ }^{-1}$ ), and Douglas-fir ( 250 trees $\mathrm{ha}^{-1}$ ) were planted during the regeneration phase to increase the multifunctionality.

The production-oriented scenario (Table A 2 and Fig. 1) focused on the production of wood, following the expected increase in the demand for wood products in Europe (Hurmekoski et al. 2015; O’Brien and Bringezu 2018). The amount of harvested wood was set as the first priority by reducing the rotation period and promoting conifers and fast-growing tree species. In the production-oriented scenario, stem reduction was applied on deciduous tree species, removing up to $25 \mathrm{~m}^{3} \mathrm{ha}^{-1}$ per intervention, while no stem reduction was applied to conifer-dominated stands. In the deciduous stands starting at a dominant height of $12 \mathrm{~m}$ up to $17 \mathrm{~m}$, a selective thinning and a thinning from below were then applied removing up to $25 \mathrm{~m}^{3} \mathrm{ha}^{-1}$. The final felling was conducted by minor selective thinning and a target diameter felling of trees with a dbh between 20 and $200 \mathrm{~cm}$ and a removal of up to $500 \mathrm{~m}^{3}$ of the standing volume. In the 
(a) age-class spruce stand

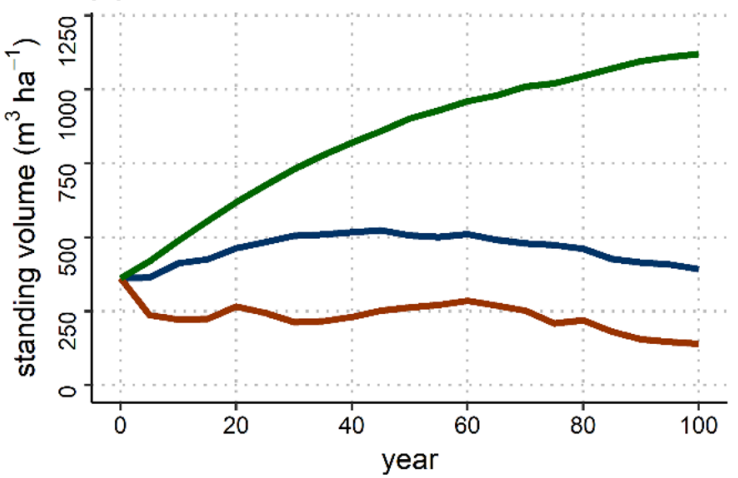

(c) age-class beech stand

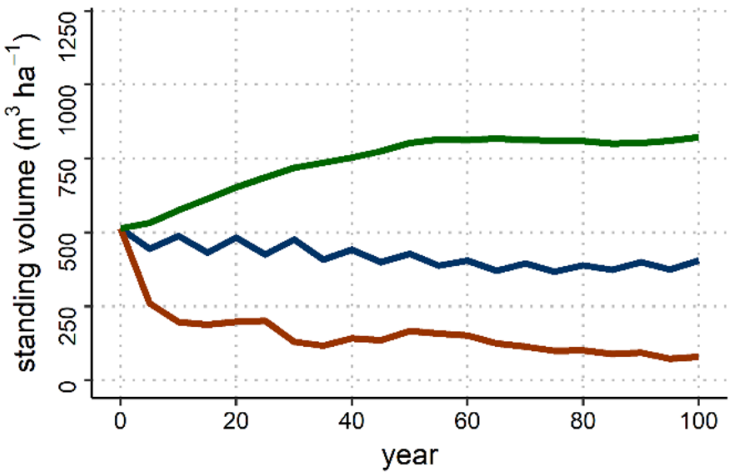

(e) age-class single-tree mixed stand

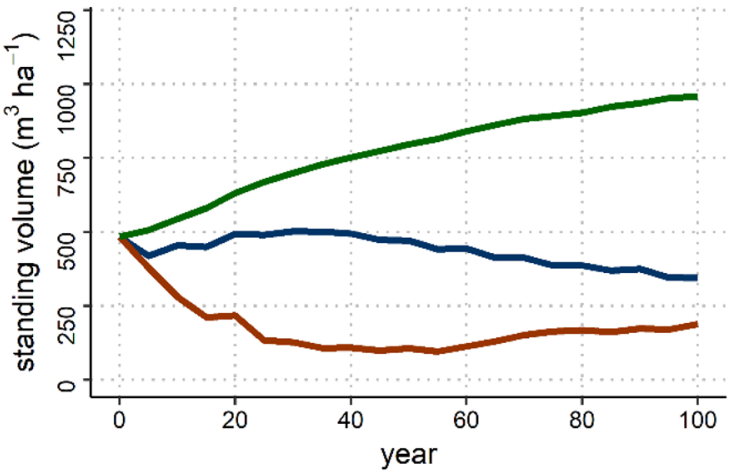

(f) age-class section-wise mixed stand

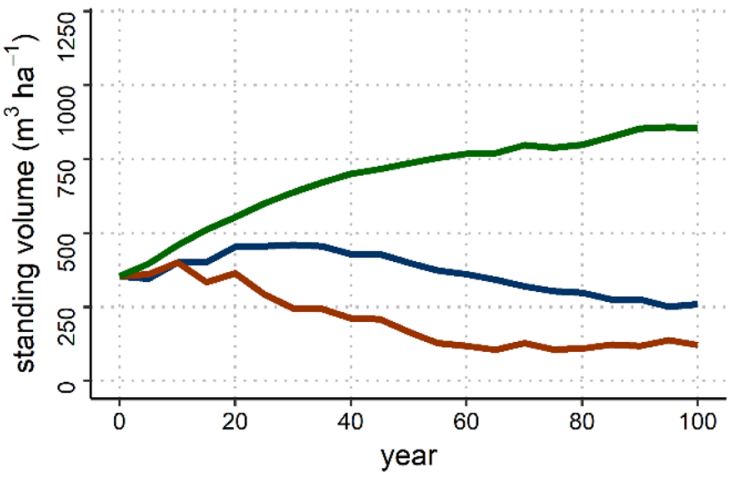

(b) uneven-aged spruce stand

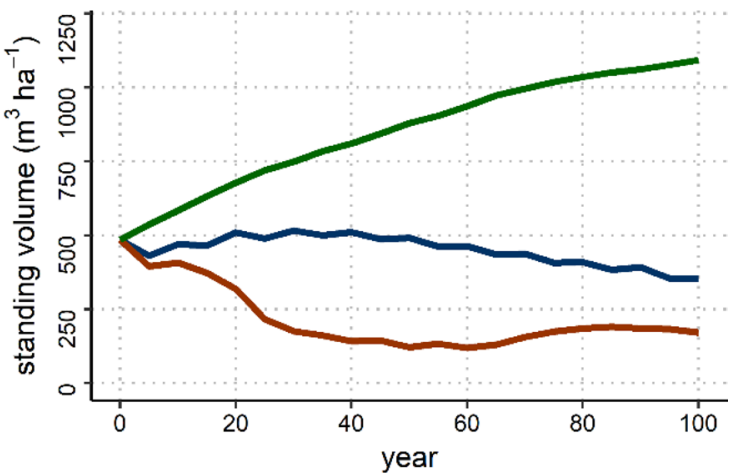

(d) uneven-aged beech stand

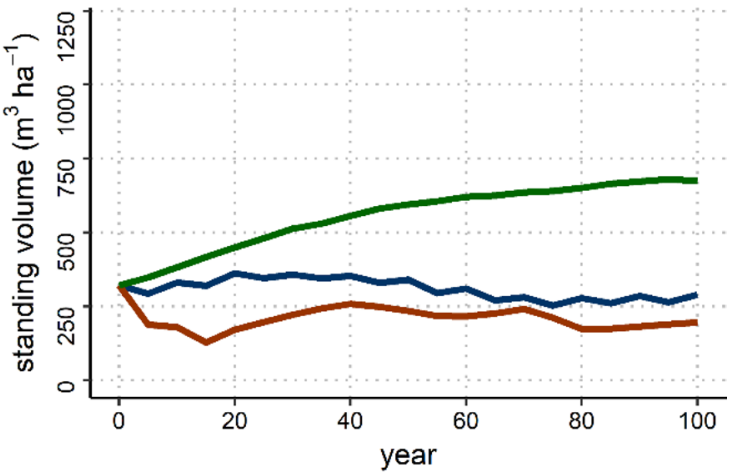

(f) uneven-aged single-tree mixed stand

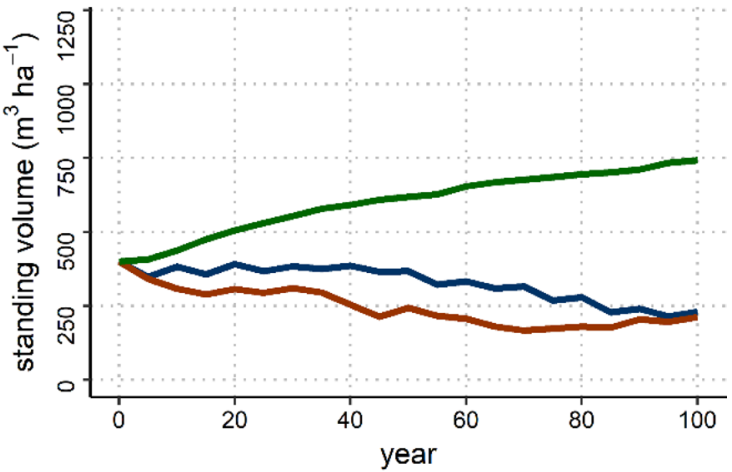

(g) uneven-aged section-wise mixed stand

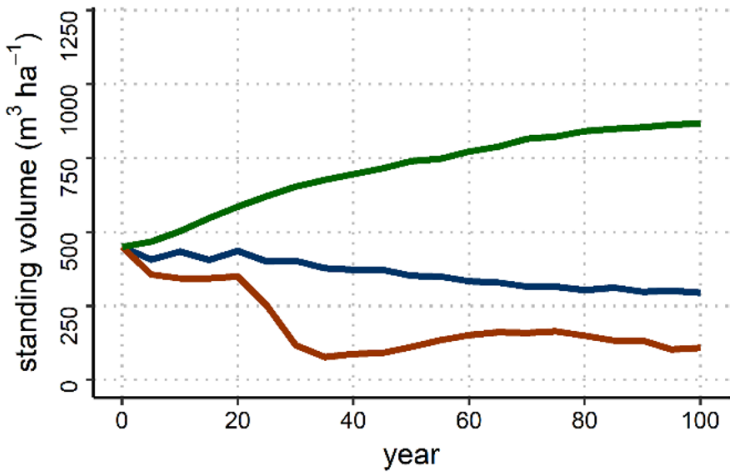

multifunctional $=$ production-oriented $=$ set-aside

Fig. 1 Standing volume in the different stands (each 192 ha) under the multifunctional (blue), production-oriented (red), and set-aside (green) scenario 
conifer stands, strong selective thinning and target diameter felling were applied in two height phases. During the first phase from 12 to $19 \mathrm{~m}$ dominant height up to $60 \mathrm{~m}^{3} \mathrm{ha}^{-1}$ was removed targeting conifers with a dbh between 40 and $200 \mathrm{~cm}$ and deciduous trees with diameters $>5 \mathrm{~cm}$. During the second phase up to $120 \mathrm{~m}^{3} \mathrm{ha}^{-1}$ of standing volume was removed for diameters between 50 and $200 \mathrm{~cm}$ for all species. The final felling phase was aimed at trees with a height $>31 \mathrm{~m}$, applying a light selective thinning and a target diameter felling with a removed standing volume of up to $500 \mathrm{~m}^{3} \mathrm{ha}^{-1}$ and a diameter between 5 and $200 \mathrm{~cm}$ for deciduous trees and a diameter between 20 and $200 \mathrm{~cm}$ for conifers. In this scenario, in addition to natural regeneration (Poschenrieder et al. 2018), Norway spruce (4000 trees $\mathrm{ha}^{-1}$ ), and Douglas-fir (Pseudotsuga menziesii) (100 trees $\mathrm{ha}^{-1}$ ) were planted during the regeneration phase.

\section{Characterizing the forest stands}

We selected the coefficient of variation of dbh (diameter at breast height $(1.3 \mathrm{~m})$ ) for our study because it is a commonly used measurement (Pretzsch 2009; del Río et al. 2015; Fischer and Mölder 2017) and is suitable for describing stand structural heterogeneity in general. The Stand Density Index (SDI) by Reineke (Reineke 1933) was included as an independent variable to cover the potential effects of stand density on stand structure. The standing volume $\left(\mathrm{m}^{3} \mathrm{ha}^{-1}\right)$ was estimated based on dbh, tree height, and form factors following the DESER standard (Johann 1993) and represents the merchantable wood volume $(\log$ size $>7 \mathrm{~cm}$ diameter at smaller end) per hectare and year $\left(\mathrm{m}^{3} \mathrm{ha}^{-1}\right)$. The volume increment ivol was defined by the increment in the standing volume per ha and year $\left(\mathrm{m}^{3} \mathrm{ha}^{-1} \mathrm{yr}^{-1}\right)$. The relative volume increment in $\%$ of the standing volume $\left(\mathrm{m}^{3} \mathrm{ha}^{-1}\right)$ rel.ivol was included in the descriptive part to visualize the development of stand productivity in the different management scenarios.

\section{Trade-off}

For the calculation of the trade-off between structural heterogeneity (dbh.cv) and productivity (ivol), both indicators were standardized for a comparable value range as applied by others (Bradford and D'Amato 2012; Qin et al. 2015). Standardized indicators are referred to as str and prod, respectively:

$$
\begin{aligned}
& \operatorname{str}_{i, j, k}=\frac{d b h . c v_{i, j, k}-\min \left(d b h . c v_{i}\right)}{\max \left(d b h . c v_{i}\right)-\min \left(d b h . c v_{i}\right)} \\
& \operatorname{prod}_{i, j}=\frac{i \operatorname{vol}_{i, j}-\min \left(\operatorname{ivol}_{i}\right)}{\max \left(\operatorname{ivol}_{i}\right)-\min \left(\operatorname{ivol}_{i}\right)}
\end{aligned}
$$

$\mathrm{i}, \mathrm{j}$, and $\mathrm{k}$ indicate stand, year, and radius, respectively. The mean value of ivol $\left(\mathrm{m}^{3} \mathrm{ha}^{-1}\right.$ year $\left.^{-1}\right)$ per stand was calculated, because productivity was of interest only at the level of the whole stand. The stand was seen as a profit-making forest enterprise where the total value is of importance. The min and max are the minimum and maximum of dbh.cv of all stands, years, and spatial scales. The standardized str and prod values ranged from 0 to 1 .

The trade-off between the standardized structural heterogeneity str and the standardized productivity prod was then set up. The trade-off therefore describes the level of structural heterogeneity in relation to a certain level of productivity. In this way, the relative level of structural heterogeneity per unit of productivity can be measured, even if stands have a different absolute level of productivity:

$t_{i, j, k}=\frac{\operatorname{str}_{i, j, k}}{\operatorname{prod}_{i, j}}$

$t_{i, j, k}$ is the trade-off between str and prod on stand $i$ in year $j$ on the spatial scale $\mathrm{k}$ and prod of stand $\mathrm{i}$ in year $\mathrm{j}$. A larger $\mathrm{t}$ value means that a stand provides more structural heterogeneity per unit of productivity. The trade-off $t$ was calculated for each stand, point in time, radius, and each of the three management scenarios.

\section{Statistical analysis}

After a descriptive presentation, we used generalized additive mixed models (GAMMs) of the mgcv package (Wood 2017; R Core Team 2018) to examine how the trade-off between structural heterogeneity and productivity ivol developed over time and with spatial scale under different management scenarios. For each of the two groups "age-class stands" and "uneven-aged stands," the model function was applied to test differences for significance. The model was also applied to the spruce stand, beech stand, single-tree mixture, and section-wise mixture but those results were only presented visually as they were not the main focus of this study.

$t_{\text {group }}=$ scen $*\left(f\left(S D I_{i}\right)+f\left(\right.\right.$ year $\left._{j}\right)+f\left(\right.$ radius $\left.\left._{k}\right)\right)+\varepsilon$

t was the trade-off str/prod per group (age-class vs. uneven-aged) in each initial stand i depending on the SDI, time (year) $j$, and space (radius) $k$. SDI for each stand i was included in the model function to cover effects that were only based on stand density. Scen was the management scenario applied. The virtual forest stand i was also included as random effect to cover unknown dependencies between the forest stands. The model term $\varepsilon$ covered the remaining unexplained variation. Smoothing terms in the mgcv package are generally based on low-rank versions of splines. We used thin plate regression splines and set bs = "ts," which can be 
applied for any number of covariates. The number of knots was chosen automatically by generalized cross-validation after manually trying out several degrees of freedom that showed to substantial change in the results.

For testing the differences between the two groups "ageclass stands" vs "uneven-aged stands," another model (GAMM) was set up that was applied to each of the three scenarios separately:

$t_{\text {scen }}=$ group $_{*}\left(f\left(S D I_{i}\right)+f\left(\right.\right.$ year $\left._{j}\right)+f\left(\right.$ radius $\left.\left._{k}\right)\right)+\varepsilon$

$\mathrm{t}_{\text {scen }}$ was the trade-off str/prod in scenario scen. The factor variable group contained the age-class vs. uneven-aged stands. The other variables were used as mentioned above.

\section{Results}

We answered the research question: "How do stand structural heterogeneity and productivity in age-class vs. uneven-aged stands develop over time and with spatial scale in different management scenarios?" with a descriptive presentation (3.1. Structural heterogeneity and relative productivity over time) and by applying models for investigating the trade-off between structural heterogeneity and productivity (3.2. Trade-off between structural heterogeneity and productivity).

\section{Structural heterogeneity and relative productivity over time}

First, we provided an overview of the structural heterogeneity dbh.cv and the relative productivity rel.ivol over time in the different scenarios (Fig. 2).

In the age-class forest, a strong increase in the dbh.cv to $>0.70$ was found for all scenarios in year 20, due to the regeneration ingrowth (Fig. 2, I row 1). After that, the dbh. $\mathrm{cv}$ decreased in the multifunctional and the production-oriented scenario resulting in a final value of $\sim 0.7$ and $\sim 0.5$, respectively. In the set-aside scenario, the dbh.cv remained higher over time and stabilized around 0.8. In the unevenaged stands (Fig. 2,II row 1), the dbh.cv increased up to 0.8 in year 20 in all scenarios due to the regeneration ingrowth. After year 20, the dbh.cv decreased slightly in the multifunctional scenario, resulting in a value of $\sim 0.70$ after 100 years and decreased strongly in the production-oriented scenario resulting in a value of $\sim 0.40$. The set-aside scenario led to a slight increase in dbh.cv up to a value of $\sim 0.90$.

The rel.ivol in age-class stands (Fig. 2, I row 2) was highest in the production-oriented scenario and stabilized around 5\% over time. In the multifunctional scenario, the rel.ivol was around 3\% and also mostly stable over time. In the set-aside, the rel.ivol was lowest and resulted in a value of $\sim 2 \%$ in the long-term. In the uneven-aged stands (Fig. 2, II row 2), the rel.ivol was highest in the production-oriented scenario, compared to the other scenarios, with an increase from $4 \%$ up to $7.5 \%$ until year 60 and a decrease to $5 \%$ after that. In the multifunctional scenario, the rel.ivol remained
Fig. 2 Coefficient of variation of dbh (dbh.cv) and the relative ivol rel.ivol (\%) in (I) age-class stands and (II) uneven-aged stands over time in the multifunctional, production-oriented, and set-aside scenario. Confidence intervals at $95 \%$
(I) age-class stands
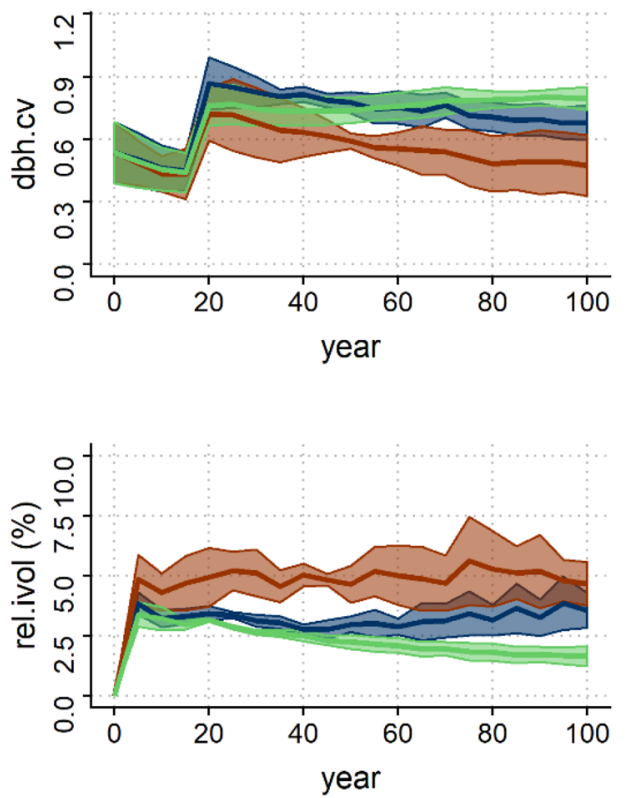

-multifunctional -production-oriented - set-aside
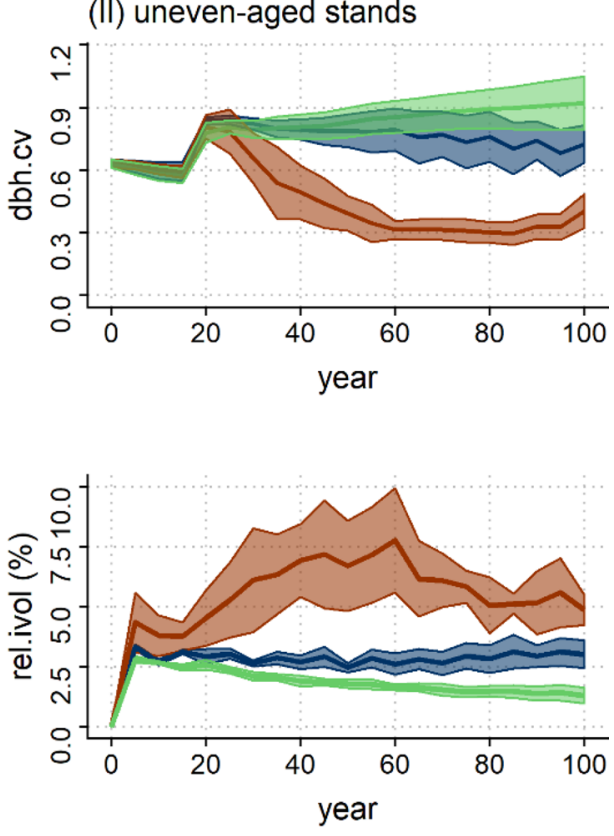

(II) uneven-aged stands 
at $2.5 \%$. In the set-aside scenario, a decrease from $2.5 \%$ to $\sim 2 \%$ was found.

In sum, whereas in the age-class stands (Fig. 2) I the rel. ivol and dbh.cv were mostly stable over time, the production-oriented scenario led to contradicting trends of dbh.cv and rel.ivol in the uneven-aged stands (Fig. 2). The descriptive part of the results already pointed at the conflicting relationship or trade-off between structural heterogeneity and productivity. For further investigation of this contrary trend, the trade-off between structural heterogeneity and productivity (str/prod) was set up and analyzed using the stated models.

\section{Trade-off between structural heterogeneity and productivity}

The models showed changes in the trade-off between the standardized structural heterogeneity str and the standardized productivity prod (str/prod) over time and with spatial scale depending on the applied silvicultural management while covering the potential effects of the SDI. The first model (Eq. 4) tested the difference in the above-mentioned relationships between the management scenarios. The second model (Eq. 5) examined the differences between ageclass forest and uneven-aged forest. The models contained the significant variables. Non-significant variables were automatically excluded during the model run. Yet, GAMMs are generally best interpreted by visual examination. The black line in the graphs represented all age-class and uneven-aged stands, respectively, each containing a pure spruce stand, a pure beech stands, a single-tree mixed stand, and a section-wise mixed stand. The separation into pure and mixed spruce and beech stands was presented only visually by the differently colored model curves, as the difference between species was not the main focus of this study. If the difference between the different mixtures was relevant, it was seen in confidence bands that did not overlap. The model curves were centered around 0 , meaning that the intercept was the overall mean of the response variable. The curves did therefore not only vary inside the span of the dependent variable but showed a negative $(<0)$ or positive $(>0)$ effect of the explaining variables on the mean of the response variable. We focused on describing only effects that were both significant and relevant because of their extent; that is to say, the effects that were also visually present.

SDI has been included in the model to cover the potential relationship between stand density and productivity (Table A 3). In the age-class stands, in the multifunctional and the set-aside scenarios, the effect of SDI was switching from positive to negative at an SDI of around 800 (Fig. 3, row 1 , a and c). In the production-oriented scenario, SDI had a mostly negative effect on str/prod in the valid range covered with enough data (Fig. 3, row 1, b). In the uneven-aged stands, in the multifunctional and the set-aside scenario, SDI had a negative effect on str/prod when an SDI was below 400 (Fig. 4, row 1, a and b). Only in the production-oriented scenario, the effect of SDI was positive up to an SDI of around 700 . For a SDI $>700$, an increasing SDI led to a lower str/prod. The effect of SDI on str/prod was found to be significantly different between age-class and uneven-aged forest (Table A 4).

Over time in the age-class stands, a significant difference in str/prod between the scenarios was found (Table A 3), especially between the multifunctional (Fig. 3, row 2, a) and the production-oriented scenario (Fig. 3, row 2, b). This difference was mostly seen in the pure beech stand, where str/ prod decreased over time only in the multifunctional scenario. In the set-aside scenario (Fig. 3, row 3, c), str/prod increased toward year 100, whereas in the other scenarios, the effect only a slight positive effect over time was found.

The most important finding in uneven-aged stands was the difference in the development of str/prod between the multifunctional (Fig. 4, row 2, a) and the production-oriented scenario (Fig. 4, row 2, b). Only in the productionoriented scenario, the str/prod increased strongly until year 20. After year 40, the effect of time on str/prod became negative, meaning a decrease in str/prod. Only in the setaside scenario, the str/prod increased over time in both pure and mixed stands. The largest difference (by visual checks) between the species in uneven-aged stands was seen in an increase in str/prod after year 50 in pure age-class spruce stands, where str/prod decreased over time in the multifunctional but not in the production-oriented scenario (Fig. 4, row 2 , a). The second model confirmed the significant difference between age-class and uneven-aged (Table A 4) concerning the development of str/prod over time. This was most clearly seen in the production-oriented scenario stands (Fig. 4, row 2, b versus Fig. 3, row 2, b).

In both age-class and uneven-aged stands, a stronger increase in str/prod with increasing spatial scale was found in the production-oriented scenario (Fig. 3, row 3, b and Fig. 4, row 3, b) compared to the multifunctional and the set-aside scenarios (Fig. 3, row 3, a and c and Fig. 4, row 3, a and c) (Table A 3). The increase in str/prod with increasing spatial scale in the multifunctional and the productionoriented scenarios was found to be significantly stronger in age-class stands than in the uneven-aged stands (Fig. 3, row 3, $a$ and $b$ and Fig. 4, row 3, a and b) (Table A 4).

\section{Results summary}

The production-oriented scenario led to a decrease over time in structural heterogeneity in the uneven-aged stands, but not in the age-class stands. In cases where a high productivity was the first priority, age-class stands could be used without lowering the structural heterogeneity. With increasing spatial 
(I) age-class stands

(a) scenario multifunctional
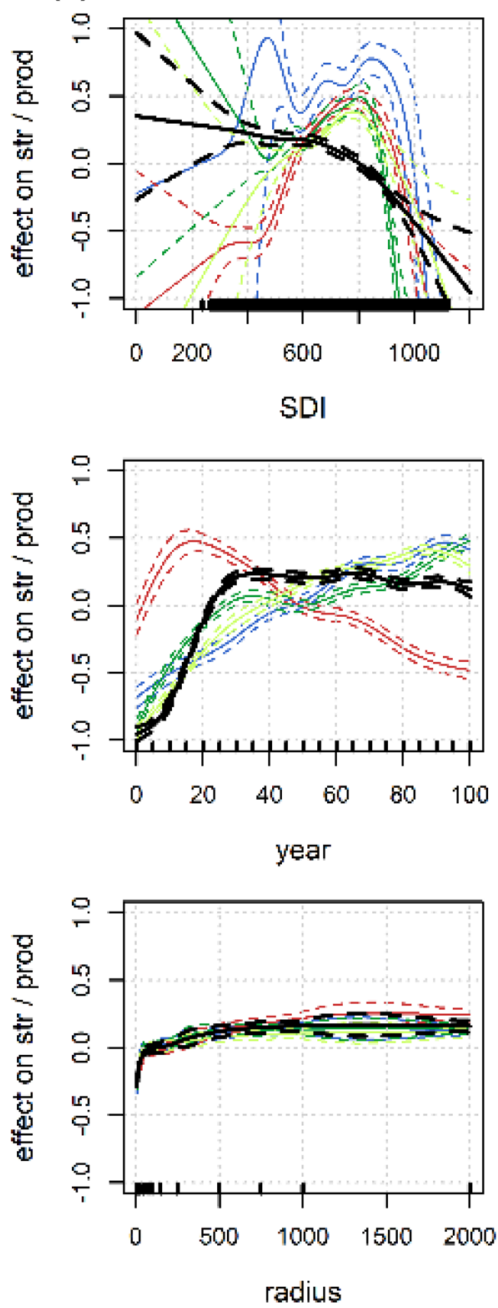

- spruce

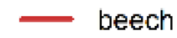

(b) scenario production-oriented
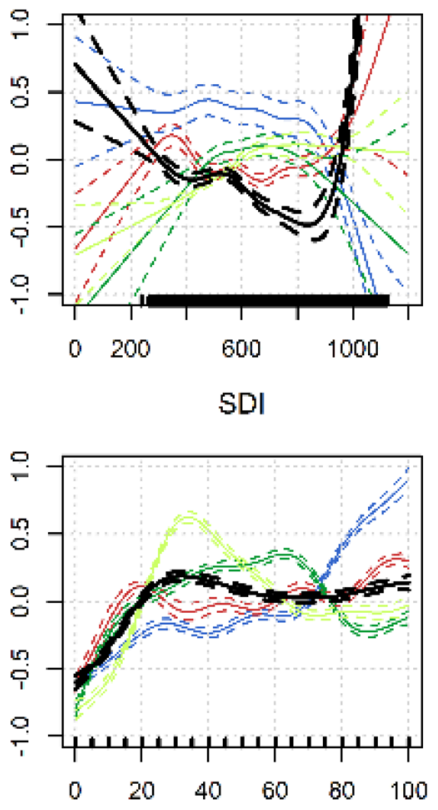

year

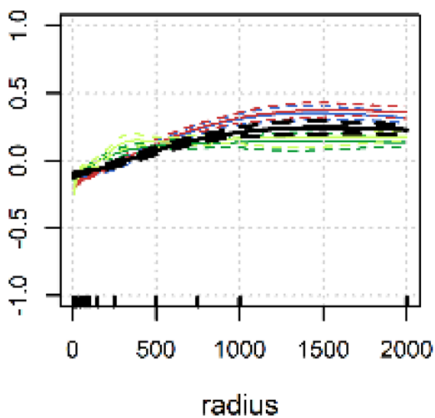

radius

(c) scenario set-aside
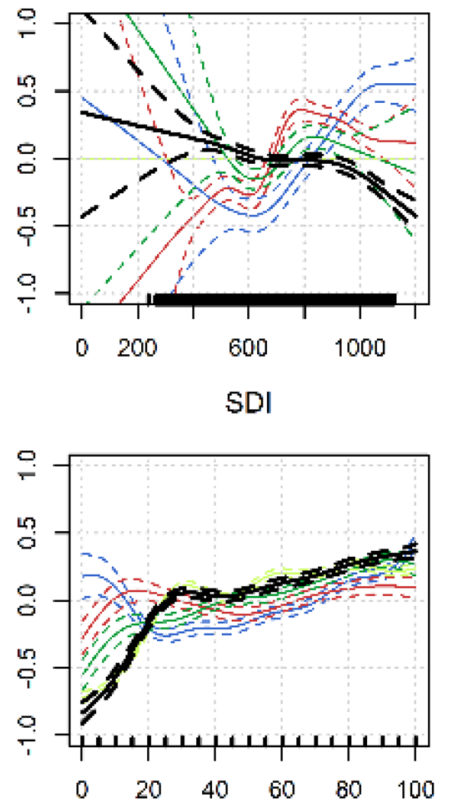

year

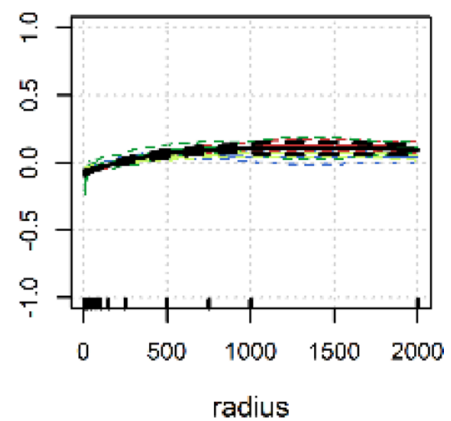

radius

$\operatorname{mix}$ (patches) $\longrightarrow$ all
Fig. 3 Model results showing the development of the effect on the trade-off coefficient of variation/ivol in the examined area in (I) ageclass stands depending on SDI (row 1), over time (row 2), and with

scale, str/prod increased more strongly in the age-class stands than in the uneven-aged stands and more strongly in the production-oriented scenario than in the multifunctional and set-aside scenarios.

\section{Discussion}

Since the demand for wood products in Europe is presumed to increase in the future (Reid 2005), management is expected to retain a strong focus on wood production, spatial scale (row 3) in a a multifunctional, b production-oriented, and $\mathbf{c}$ set-aside scenario. Confidence intervals at $95 \%$

even though other ecosystem functions and services need to be covered as well (Sikkema et al. 2017). Most forests in Europe are managed, which enables decision makers in forest management to shape the outcome of ecosystem functions and services. Usually, except of in uneven-aged forests, tree size heterogeneity within a production-class decreases as soon as a forest is economically managed (Buongiorno et al. 1994). We noted this trend in the descriptive part of the analysis (Fig. 2). We then quantified the conflicting interest between high wood production and high structural heterogeneity by using a trade-off value (Fig. 3 and Fig. 4). 


\section{(II) uneven-aged stands}

(a) scenario multifunctional
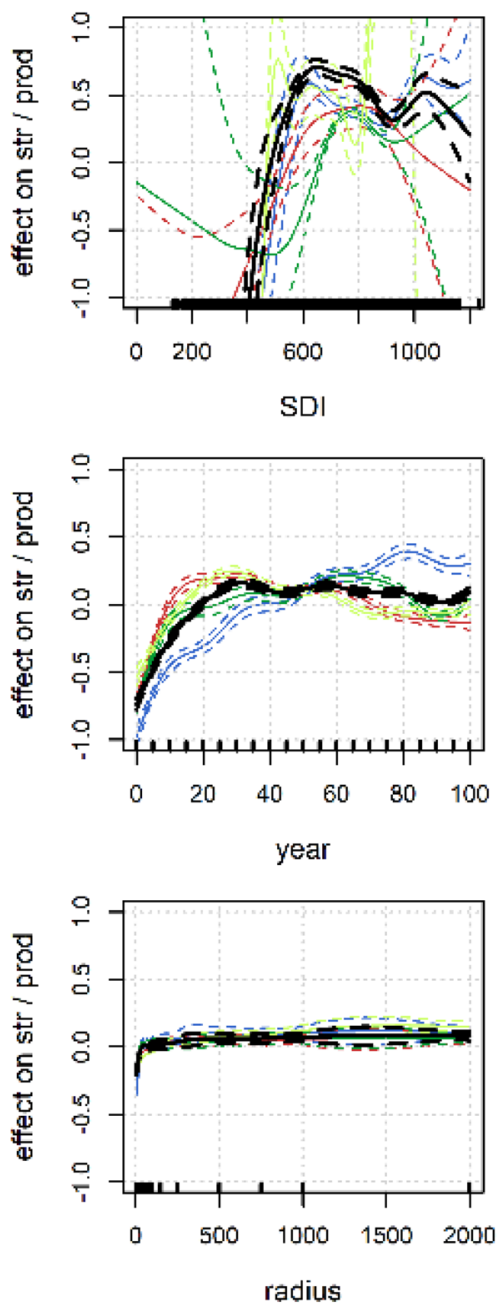

- spruce (b) scenario production-oriented
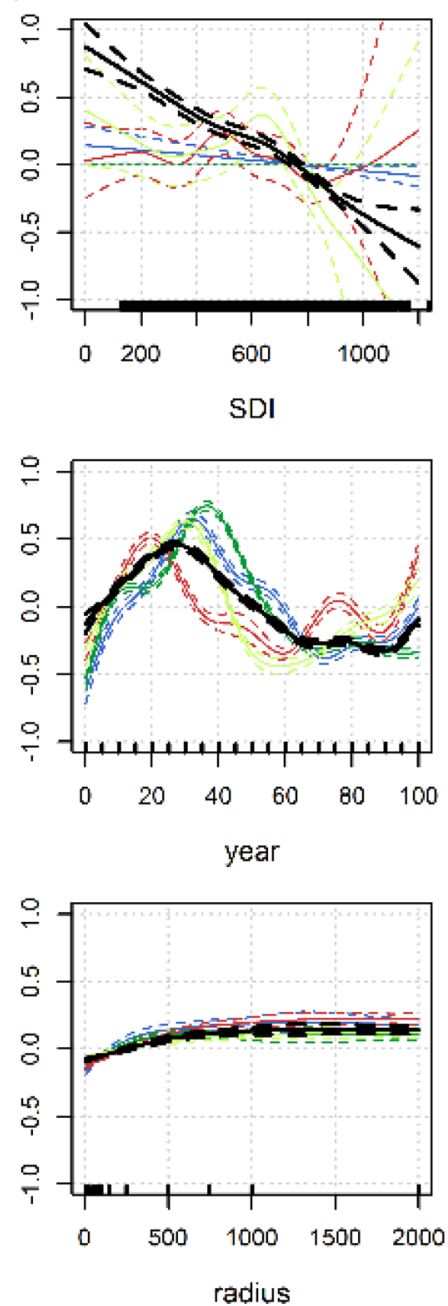

radius (c) scenario set-aside
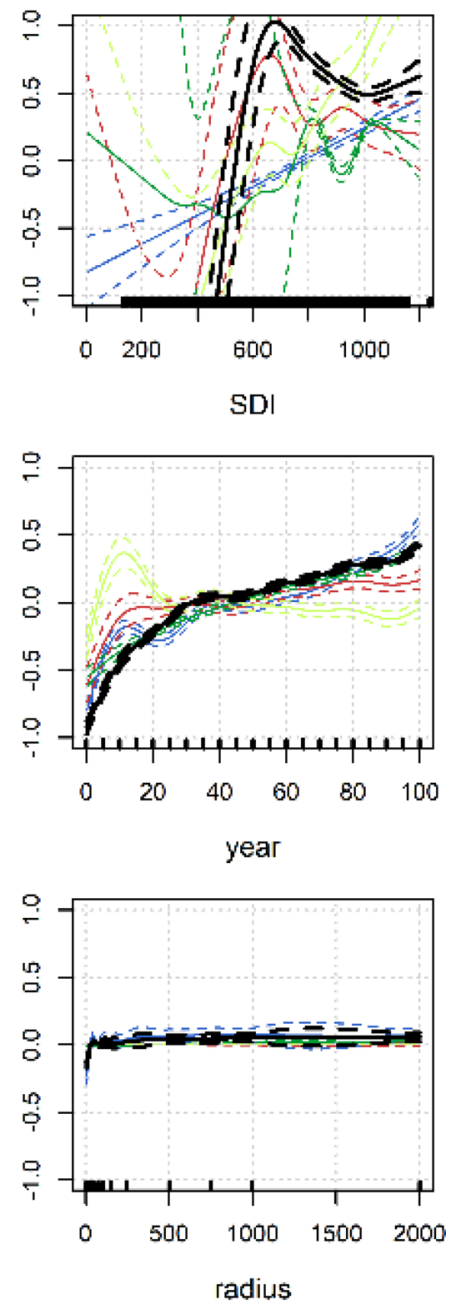

mix (patches) - all
Fig. 4 Model results showing the development of the effect on the trade-off coefficient of variation/ivol in the examined area in (II) uneven-aged stands depending on SDI (row 1), over time (row 2),

We used standardized measures to disentangle the trade-off from absolute values (which depended also on the setup of the virtual stands) in order to develop a ratio of structural heterogeneity per unit of productivity. An increase in the trade-off str/prod could therefore result from an increase in structural heterogeneity str or in a decrease in productivity prod. The focus on a high productivity remained the first priority and was incorporated already in the management scenarios (multifunctional, production-oriented, set-aside). and with spatial scale (row 3) in a a multifunctional, b productionoriented, and $\mathbf{c}$ set-aside scenario. Confidence intervals at $95 \%$

If similar analyses are conducted on other plots with an overall lower or higher level of productivity, the conflicting relationship between structure and productivity can still be measured and compared.

Differences between the management scenarios and between age-class and uneven-aged stands were visible in the descriptive part of the results (Fig. 2) and statistically tested through the application of the models (Eq. 4, Eq. 5 and Fig. 3 and Fig. 4). 
The inclusion of SDI in the models used in this study enabled the specific testing of the effect of silvicultural management on structural heterogeneity in relation to stand productivity as it covered potential effects of higher stocking on stand structure and productivity (Uhl et al. 2015). In the age-class stands, SDI was negatively correlated with str/prod which indicated that a higher stocking led to a higher productivity without leading to higher structural heterogeneity. In the uneven-aged stands, a higher SDI in combination with the multifunctional and set-aside scenario led to a higher str/prod, which can be explained by the focus of those two scenarios on species mixing and on a multi-layered stand through regeneration with different species (Fig. 3, row 1 and Fig. 4, row 1).

In the production-oriented scenario, the structural heterogeneity per unit of productivity str/prod decreased significantly over time in the case of the uneven-aged stands, compared to the age-class stands. The prescribed thinning in the production-oriented scenario incorporated a commercial use of competitor trees through regular thinning from below. In uneven-aged stands, the thinning operations were applied to the whole forest stand at the same time, which can lead to a more homogeneous tree size distribution resulting in a lower structural heterogeneity, as stated by others (Gradel et al. 2017). In the age-class stands, however, each age-class was thinned individually depending on tree height. A higher number of different age-classes and tree heights was therefore possible, at least when measured at the whole stand.

Those results are only valid when assuming a provision of structural heterogeneity at stand level instead of tree level. With increasing spatial scale, the structural heterogeneity per unit of productivity changed more strongly in age-class stands compared to uneven-aged stands due to the mosaic of differently aged strata next to each other. The maximum structural heterogeneity in age-class stands was therefore reached at a larger spatial scale. Also, str/prod increased with increasing spatial scale more strongly in the production-oriented scenario compared to the multifunctional and the set-aside scenario. In both cases, the thinning operations rather homogenized the tree size distribution at a small spatial scale (through strong thinning from below in the production-oriented scenario and through the same type of thinning applied to a whole age-class in the age-class stands). In the multifunctional or set-aside scenarios, especially in uneven-aged stands, the selective thinning maintained a higher structural heterogeneity at tree level. With increasing spatial scale, the structural heterogeneity did therefore not increase so strongly because it was already high at tree level. If the size of each age-class is rather small (16 ha in this study), differently aged and sized trees can provide a heterogeneous forest even under the production-oriented scenario. This finding is especially interesting as the consequences can be a higher structural heterogeneity in age-class stands compared to uneven-aged stands (Schall et al. 2018a; Nolet et al. 2018), when measured at a larger spatial scale, due to the provided mosaic of different habitat types (Terraube et al. 2016). Also, when considering the overall higher relative productivity in the production-oriented scenario (Fig. 2, row 2 ), only the age-class stand could maintain a high structural heterogeneity through its mosaic of different age-classes. The need for open spaces, e.g., for light-demanding species, (Emborg 1998) can be embedded in a large heterogeneous mosaic and influence biodiversity at the landscape scale (Arellano and Halffter 2003; Zhang et al. 2015). Further can the stability at landscape scale be increased through this higher structural heterogeneity (Gardiner et al. 2005). Still, commercially used age-class forests are often assumed to provide a lower number of large and old trees, as most trees are cut before reaching the old-growth phase. This could be addressed through a set-aside of parts of the managed forests, as suggested by others (Simonsson et al. 2015). The virtual forest stands were based on real forest types in Bavaria. They are representative of forest ecosystems in Central Europe and enable an analysis of the effect of silvicultural management. For testing the performance of forests under different management in terms of trade-offs between ecosystem functions and services in advance of application, simulation has proven to be a useful tool (Marques et al. 2017). Still, over the large time span of 100 years, growing conditions can change and will need to be considered in future studies by incorporating climate models.

The simulation aimed at testing silvicultural management on already existing and partly mature stands. A negative or positive effect of structural heterogeneity on productivity in young and old stands, respectively, found by others (Zeller and Pretzsch 2019) could therefore not be compared to the virtual stands in this study. Further did the application of the management scenarios on the different types of stands represents a sudden shift compared to the previous management that had formed the existing forest types. Such sudden changes in management might seem unrealistic in practice. Still, also in slowly developing ecosystems, like forests, strong changes in growing conditions in the future might require prompt decisions and adjustments of silvicultural management. Those could include, e.g., the establishment of national parks with sudden abandonment of previously managed forests or a shift from a monoculture that dropped out due to drought, to an uneven-aged mixed stand including foreign tree species. We therefore included and tested the different management scenarios on all initial stands, even if 
the scenario could be a strong contrast to previously applied management for some of the stands, e.g., a planting with deciduous trees instead of the previously dominating conifers. Such a transition in practice requires the consideration of species' traits and light and space requirements, expected changes in growing conditions, and the future demand in the different wood products. For the quantification of structural heterogeneity, we chose the coefficient of variation as it is representative for both the diameter and height differentiation of tree sizes. It can also easily be calculated based on a diameter distribution and is thus applicable in different types of inventories. Other measures of stand structural heterogeneity could of course be added in further studies due to their importance for the multifunctionality of forest ecosystems, such as the amount of deadwood (Bauhus et al. 2018), the number of tree layers, the canopy cover, or the spatial distribution of trees (Pommerening 2002).

\section{Conclusions and outlook}

Our approach of combining stand simulation with an analysis of structural heterogeneity in relation to stand productivity can be understood as an exemplary study to identify and incorporate forest structure in the simulation of forest stand growth and put it in relation to the aim of a high productivity. Continuous cover forestry has been promoted in the last decades for the purpose of increasing uneven-aged stands in temperate (Knoke 2012; von Gadow et al. 2002) and boreal regions (Bergeron et al. 2002; Kuuluvainen et al. 2012; Axelsson and Angelstam 2011). This shows that the transition of age-class stands to uneven-aged forest stands is an up-to-date topic due to the importance of a high structural heterogeneity for multiple ecosystem functions and services (Pohjanmies et al. 2017). A comparison between stand types in terms of their performance in structural heterogeneity and productivity can help to estimate the outcome of management before transforming existing age-class stands to uneven-aged stands. Possibly, existing age-class stands can provide a high structural heterogeneity at a slightly larger spatial scale. We found this to be the case in the simulated age-class stands in the production-oriented scenario of this study, where a high structural heterogeneity and high productivity could be ensured, at least at stand level. Of course, simulating the growth of virtual forest stands over a range of 100 years cannot directly lead to guidelines for the forest practice since silvicultural management only represents one of many factors determining the performance of forest ecosystems. Our approach rather represents a small step toward an infrastructure that shall estimate forest growth under certain conditions and can later be connected to models considering long-term changes in climate, growing conditions, and population dynamics. Our study shall increase the awareness of the importance of forest structure at different spatial scales and the possibilities for forest management to modify stand structure when dealing with a conflict of interest between different ecosystem functions and services in multifunctional forests.

Acknowledgements We thank the Bavarian State Ministry for Nutrition, Agriculture, and Forestry for permanent support of the project "W 07 Long-term experimental plots for forest growth and yield research" [\#7831-22209-2013]. We also thank the European Union for funding of the project "Management of mixed-species stands. Options for a low-risk forest management (REFORM)" [\#2816ERA02S].

Author contributions LZ contributed to conceptualization and writing - original draft; LZ and ATC were involved in methodology; HP contributed to supervision; ATC and HP were involved in writing review \& editing.

Funding Open Access funding enabled and organized by Projekt DEAL. This research was funded by the German Research Foundation (DFG) and the Technical University of Munich within the funding program "Open Access Publishing." Further has this research been supported in parts by the BiodivERsA project "GreenFutureForests" [\#01LC1610B], by the FORD project Biotip [\#01LC1716D] promoted by the German Aerospace Center (DLR) and the German Federal Ministry of Education and Research. Further was this research financially supported by the German Federal Ministry of Food and Agriculture (BMEL) through the Federal Office for Agriculture and Food (BLE) [\#2816ERA02S].

\section{Compliance with ethical standards}

Conflict of interest The authors declare no conflict of interest.

Open Access This article is licensed under a Creative Commons Attribution 4.0 International License, which permits use, sharing, adaptation, distribution and reproduction in any medium or format, as long as you give appropriate credit to the original author(s) and the source, provide a link to the Creative Commons licence, and indicate if changes were made. The images or other third party material in this article are included in the article's Creative Commons licence, unless indicated otherwise in a credit line to the material. If material is not included in the article's Creative Commons licence and your intended use is not permitted by statutory regulation or exceeds the permitted use, you will need to obtain permission directly from the copyright holder. To view a copy of this licence, visit http://creativecommons.org/licenses/by/4.0/.

\section{Appendix}

See Tables 3, 4, 5, 6 and Fig. 5, 6, 7, 8, 9, 10, 11, and 12 


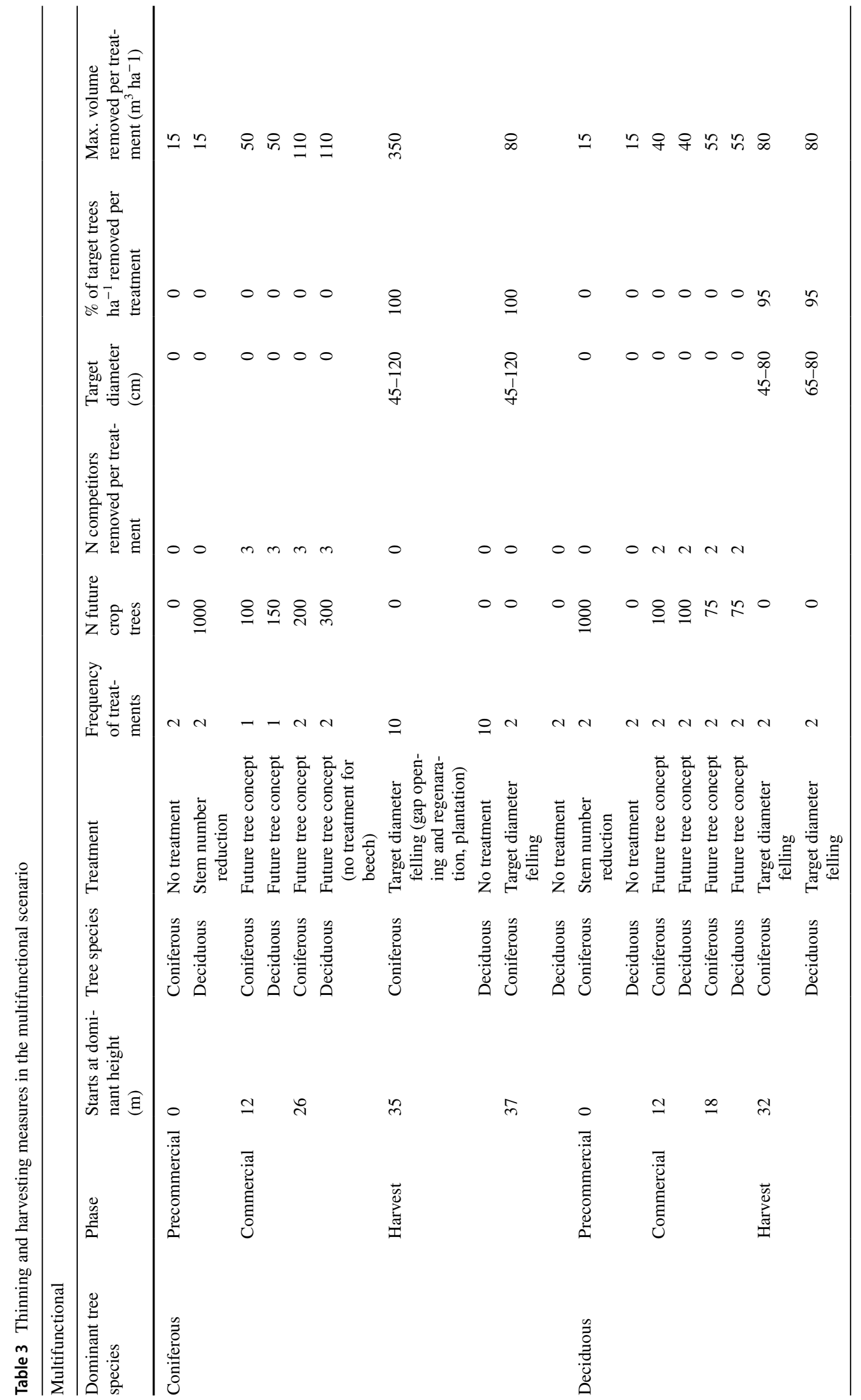




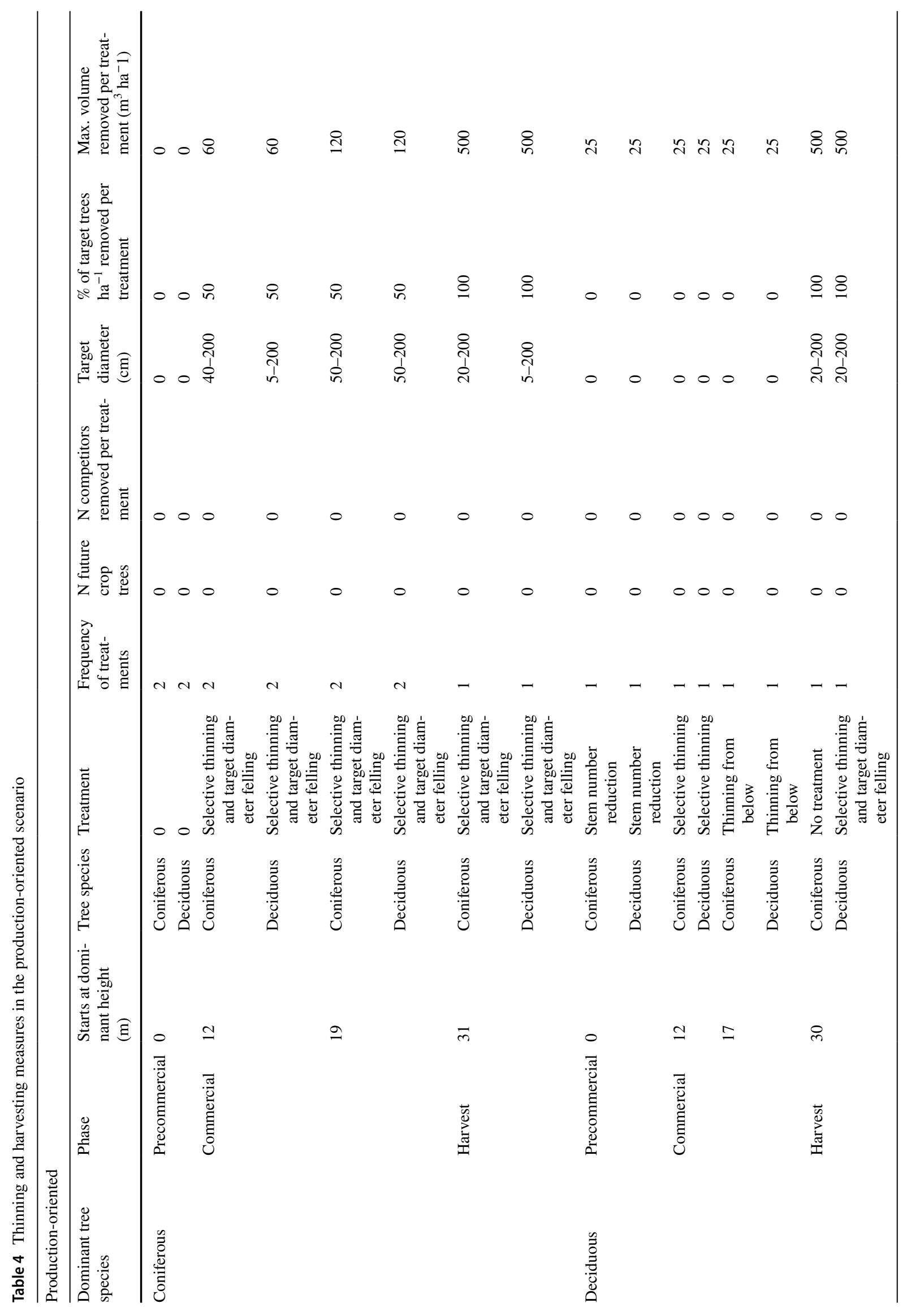


Table 5 Model results for differences between management scenarios

\begin{tabular}{|c|c|c|c|c|c|c|c|c|c|c|c|c|c|}
\hline \multirow[t]{2}{*}{ Str / prod } & \multicolumn{6}{|c|}{ Age-class } & & \multicolumn{6}{|c|}{ Uneven-aged } \\
\hline & Edf & Ref.df & $\mathrm{F}$ & $p$ value & Sig & R-sq. (adj) & & Edf & Ref.df & $\mathrm{F}$ & $p$ value & Sig & R-sq. (adj) \\
\hline s(SDI):multi & 4.05 & 9 & 16.00 & 0.000 & $* * *$ & 0.726 & $\mathrm{~s}(\mathrm{SDI})$ :scen1 & 7.18 & 9.00 & 96.86 & 0.000 & $* * *$ & 0.658 \\
\hline s(SDI):prod & 7.89 & 9 & 36.82 & 0.000 & $* * *$ & & $\mathrm{~s}(\mathrm{SDI}): \operatorname{scen} 2$ & 4.40 & 9.00 & 58.44 & 0.000 & $* * *$ & \\
\hline s(SDI):set-aside & 3.88 & 9 & 11.76 & 0.000 & $* * *$ & & s(SDI):scen6 & 5.67 & 9.00 & 72.47 & 0.000 & $* * *$ & \\
\hline s(year):multi & 8.44 & 9 & 249.70 & 0.000 & $* * *$ & & s(year):scen1 & 8.23 & 9.00 & 209.12 & 0.000 & $* * *$ & \\
\hline s(year):prod & 7.53 & 9 & 113.54 & 0.000 & $* * *$ & & s(year):scen2 & 8.46 & 9.00 & 292.27 & 0.000 & $* * *$ & \\
\hline s(year):set-aside & 7.78 & 9 & 74.28 & 0.000 & $* * *$ & & s(year):scen6 & 8.17 & 9.00 & 184.77 & 0.000 & $* * *$ & \\
\hline s(radius):multi & 7.87 & 9 & 48.03 & 0.000 & $* * *$ & & s(radius):scen 1 & 8.28 & 9.00 & 26.59 & 0.000 & $* * *$ & \\
\hline s(radius):prod & 3.02 & 9 & 38.31 & 0.000 & $* * *$ & & $\mathrm{~s}$ (radius):scen2 & 3.06 & 9.00 & 31.78 & 0.000 & $* * *$ & \\
\hline s(radius):set-aside & 2.93 & 9 & 12.69 & 0.000 & $* * *$ & & s(radius):scen6 & 8.34 & 9.00 & 17.57 & 0.000 & $* * *$ & \\
\hline
\end{tabular}

Table 6 Model results for differences between age-class and uneven-aged stands

\begin{tabular}{|c|c|c|c|c|c|c|}
\hline \multicolumn{7}{|l|}{ Multifunctional } \\
\hline & edf & Ref.df & $\mathrm{F}$ & $p$ value & sig & $\mathrm{R}$-sq \\
\hline s(SDI):age-class & 4.58 & 9 & 21.94 & 0.000 & $* * *$ & \multirow[t]{6}{*}{0.653} \\
\hline s(SDI):uneven-aged & 6.77 & 9 & 39.14 & 0.000 & $* * *$ & \\
\hline s(year):age-class & 8.65 & 9 & 339.98 & 0.000 & $* * *$ & \\
\hline s(year):uneven-aged & 7.84 & 9 & 172.03 & 0.000 & $* * *$ & \\
\hline $\mathrm{s}$ (radius):age-class & 8.20 & 9 & 64.11 & 0.000 & $* * *$ & \\
\hline $\mathrm{s}$ (radius): uneven-aged & 7.65 & 9 & 20.37 & 0.000 & $* * *$ & \\
\hline \multicolumn{7}{|l|}{ Production-oriented } \\
\hline & edf & Ref.df & $\mathrm{F}$ & $p$ value & sig & R-sq \\
\hline s(SDI):age-class & 6.84 & 9 & 23.81 & 0.000 & $* * *$ & \multirow[t]{7}{*}{0.553} \\
\hline $\mathrm{s}(\mathrm{SDI})$ :uneven-aged & 1.66 & 9 & 29.91 & 0.000 & $* * *$ & \\
\hline s(year):age-class & 7.48 & 9 & 94.53 & 0.000 & $* * *$ & \\
\hline $\mathrm{s}$ (year): uneven-aged & 7.95 & 9 & 151.33 & 0.000 & $* * *$ & \\
\hline $\mathrm{s}$ (radius):age-class & 2.83 & 9 & 28.25 & 0.000 & $* * *$ & \\
\hline \multirow[t]{2}{*}{$\mathrm{s}$ (radius): uneven-aged } & 2.57 & 9 & 15.40 & 0.000 & $* * *$ & \\
\hline & 6.84 & 9 & 23.81 & 0.000 & $* * *$ & \\
\hline \multicolumn{7}{|l|}{ Set-aside } \\
\hline & edf & Ref.df & $\mathrm{F}$ & $p$ value & sig & $\mathrm{R}$-sq \\
\hline $\mathrm{s}(\mathrm{SDI})$ :age-class & 6.79 & 9 & 13.33 & 0.000 & $* * *$ & \multirow[t]{6}{*}{0.794} \\
\hline $\mathrm{s}(\mathrm{SDI})$ :uneven-aged & 6.54 & 9 & 29.19 & 0.000 & $* * *$ & \\
\hline s(year):age-class & 8.50 & 9 & 99.36 & 0.000 & $* * *$ & \\
\hline $\mathrm{s}$ (year):uneven-aged & 8.77 & 9 & 225.98 & 0.000 & $* * *$ & \\
\hline s(radius):age-class & 7.63 & 9 & 46.30 & 0.000 & $* * *$ & \\
\hline s(radius): uneven-aged & 8.63 & 9 & 37.49 & 0.000 & $* * *$ & \\
\hline
\end{tabular}

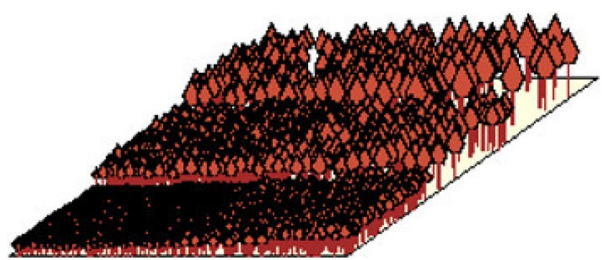

Fig. 5 Age-class spruce stand

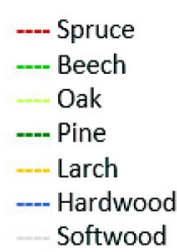

Softwood

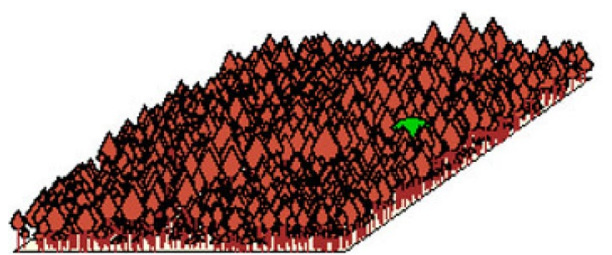

--- Spruce
--- Beech
Oak
--- Pine
- -- Larch
--- Hardwood
Softwood

Fig. 6 Uneven-aged spruce stand 


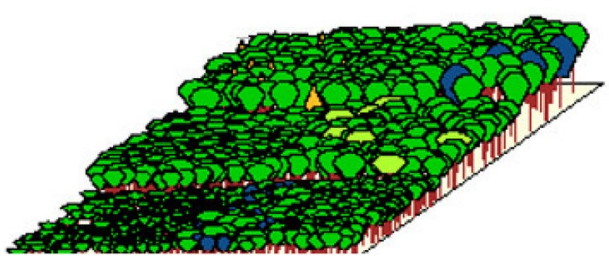

--- Spruce
--- Beech
- Oak
--- Pine
-- Larch
--- Hardwood
-Softwood

Fig. 7 Age-class beech stand

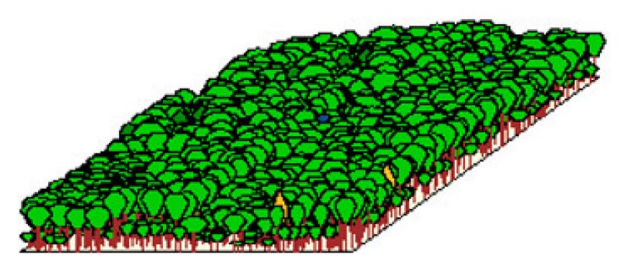

--- Spruce
--- Beech
Oak
--- Pine
- Larch
-- Hardwood
Softwood

Fig. 8 Uneven-aged beech stand

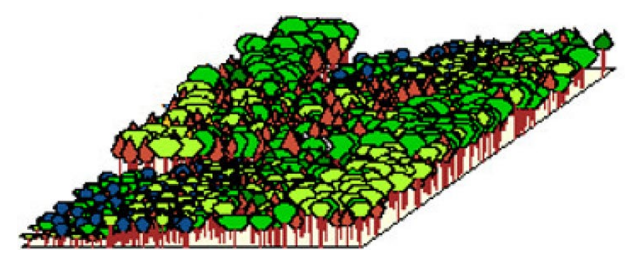

--- Spruce
--- Beech
- Oak
--- Pine
- Larch
-- Hardwood
Softwood

Fig. 9 Age-class single-tree mixed stand

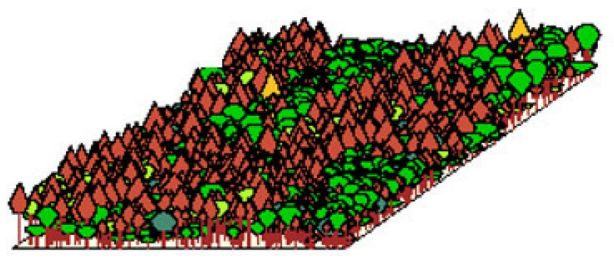

--- Spruce
--- Beech
Oak
--- Pine
- Larch
-- Hardwood
- Softwood

Fig. 10 Uneven-aged single-tree mixed stand

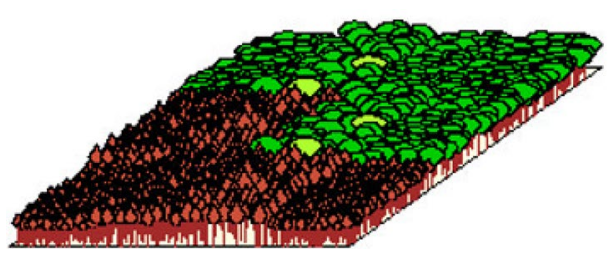

--- Spruce
--- Beech
- Oak
--- Pine
Larch
--- Hardwood
Softwood

Fig. 11 Age-class section-wise mixed stand

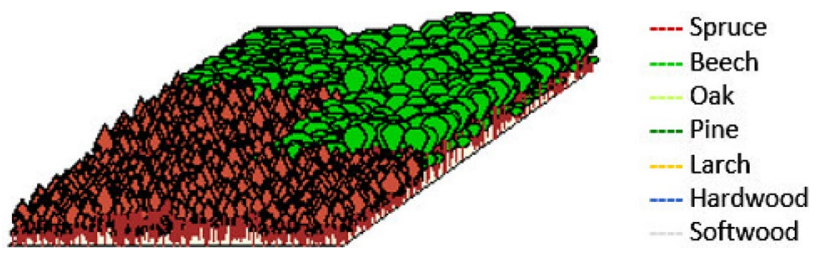

Fig. 12 Uneven-aged section-wise mixed stand

\section{References}

Ali A, Yan E-R, Chen HY et al (2016) Stand structural diversity rather than species diversity enhances aboveground carbon storage in secondary subtropical forests in Eastern China. Biogeosciences 13:4627-4635

Arellano L, Halffter G (2003) Gamma diversity: derived from and a determinant of Alpha diversity and Beta diversity an analysis of three tropical landscapes. Acta zoológica Mexicana 90:27-76

Axelsson R, Angelstam P (2011) Uneven-aged forest management in boreal Sweden: local forestry stakeholders' perceptions of different sustainability dimensions. Forestry 84:567-579

Bauhus J, Baber K, Müller J (2018) Dead Wood in Forest Ecosystems. Oxford Bibliographies. https://doi.org/10.1093/obo/9780199830 060-0196

Bayerische Staatsforsten A (2008) Waldbaugrundsätze der Bayerischen Staatsforsten. Available via https://www.baysf.de/fileadmin/user_ upload/04-wald_verstehen/Publikationen/Waldbaugrundsaetze. pdf. Accessed 8 Sep 2019

Benítez Á, Prieto M, Aragón G (2015) Large trees and dense canopies: key factors for maintaining high epiphytic diversity on trunk bases (bryophytes and lichens) in tropical montane forests. Forestry 88:521-527

Bergeron Y, Leduc A, Harvey BD, Gauthier S (2002) Natural fire regime: A guide for sustainable management of the Canadian boreal forest. Silva Fennica 36(1):81-95. https://doi. org/10.14214/sf.553

Bhakti T, Goulart F, de Azevedo CS et al (2018) Does scale matter? the influence of three-level spatial scales on forest bird occurrence in a tropical landscape. PLoS ONE 13:e0198732

Biber P, Borges J, Moshammer R et al (2015) How sensitive are ecosystem services in European forest landscapes to silvicultural treatment? Forests 6:1666-1695

Bohn FJ, Huth A (2017) The importance of forest structure to biodiversity-productivity relationships. Royal Soci 4:160521

Bohn FJ, May F, Huth A (2018) Species composition and forest structure explain the temperature sensitivity patterns of productivity in temperate forests. Biogeosciences 15:1795-1813

Borrass L, Kleinschmit D, Winkel G (2017) The German model of integrative multifunctional forest management-Analysing the emergence and political evolution of a forest management concept. Forest Policy and Economics 77:16-23. http://www.scien cedirect.com/science/article/pii/S1389934116301496

Bourdier T, Cordonnier T, Kunstler G et al (2016) Tree size inequality reduces forest productivity: an analysis combining inventory data for ten european species and a light competition model. PLoS ONE 11:e0151852

Bradford JB, D'Amato AW (2012) Recognizing trade-offs in multiobjective land management. Front Ecol Environ 10:210-216. https://doi.org/10.1890/110031

Brown CE (1998) Applied multivariate statistics in geohydrology and related sciences. Springer, Berlin Heidelberg, Berlin, Heidelberg 
Bundesministerium für Ernährung und Landwirtschaft BMEL (2014) Der Wald in Deutschland. Ausgewählte Ergebnisse der dritten Bundeswaldinventur. Accessed 15 Jun 2019

Bundesministerium für Ernährung, Landwirtschaft und Verbraucherschutz BMELV (2011) Forest Strategy 2020. Sustainable Forest Management -An Opportunity and a Challenge for Society. BMELV. Available via https://www.bmel.de/SharedDocs/Downl oads/EN/Publications/ForestStrategy2020.pdf?__blob=publi cationFile. Accessed 10 Nov 2019

Buongiorno J, Dahir S, Lu H-C et al (1994) Tree Size Diversity and Economic Returns in Uneven-Aged Forest Stands. For Sci 40: 83-103. https://academic.oup.com/forestscience/articlepdf/40/1/83/22549747/forestscience0083.pdf

Buongiorno J, Raunikar R, Zhu S (2011) Consequences of increasing bioenergy demand on wood and forests: An application of the Global Forest Products Model. JFE 17:214-229

Burschel P, Huss J (2003) Grundriss des Waldbaus Ein Leitfaden für Studium und Praxis: 207 Tabellen, 3rd edn. Ulmer, Stuttgart

Coll L, Ameztegui A, Collet C et al (2018) Knowledge gaps about mixed forests: What do European forest managers want to know and what answers can science provide? Forest Ecology and Management 407:106-115. http://www.sciencedirect.com/science/ article/pii/S0378112717309866

Crow TR, Buckley DS, Nauertz EA et al (2002) Effects of Management on the Composition and Structure of Northern Hardwood Forests in Upper Michigan. for sci 48:129-145. https://academic. oup.com/forestscience/article-pdf/48/1/129/22547943/forestscie nce0129.pdf

Cyganek B (2005) Adaptive Window Growing Technique for Efficient Image Matching. In: Pina P et al (eds) Marques JS, Pérez de la Blanca, Nicolás. Pattern Recognition and Image Analysis IbPRIA 2005 Lecture Notes in Computer Science. Springer, Heidelberg

Danescu A, Albrecht AT, Bauhus J (2016) Structural diversity promotes productivity of mixed, uneven-aged forests in southwestern Germany. Oecologia 182:319-333

del Río M, Pretzsch H, Alberdi I et al (2015) Characterization of the structure, dynamics, and productivity of mixed-species stands. Review and perspectives. Eur J Forest Res 135:23-49

Dieler J, Uhl E, Biber P et al (2017) Effect of forest stand management on species composition, structural diversity, and productivity in the temperate zone of Europe. Eur J Forest Res 136:739-766

Emborg J (1998) Understorey light conditions and regeneration with respect to the structural dynamics of a near-natural temperate deciduous forest in Denmark. For Ecol Manage 106:83-95

Enquist BJ, West GB, Brown JH (2009) Extensions and evaluations of a general quantitative theory of forest structure and dynamics. Proc Natl Acad Sci USA 106:7046-7051

Fedrowitz K, Koricheva J, Baker SC et al (2014) Can retention forestry help conserve biodiversity? a meta-analysis. J Appl Ecol 51:1669-1679

Felipe-Lucia MR, Soliveres S, Penone C et al (2018) Multiple forest attributes underpin the supply of multiple ecosystem services. Nature communications 9:4839. https://www.nature.com/artic les/s41467-018-07082-4.pdf

Fischer C, Mölder A (2017) Trend to increasing structural diversity in German forests: results from National Forest Inventories 2002 and 2012. Ann For Sci 74:80. https://doi.org/10.1007/s1359 5-017-0675-5

Franc N, Götmark F, Økland B et al (2007) Factors and scales potentially important for saproxylic beetles in temperate mixed oak forest. Biol Cons 135:86-98

Gamfeldt L, Snäll T, Bagchi R et al (2013) Higher levels of multiple ecosystem services are found in forests with more tree species. Nat Commun 4:1340
Gardiner B, Marshall B, Achim A et al (2005) The stability of different silvicultural systems a wind-tunnel investigation. For Int J For Res 78:471-484

Gärtner S, Reif A (2004) The impact of forest transformation on stand structure and ground vegetation in the southern Black Forest, Germany. Plant Soil 264:35-51. https://doi.org/10.1023/ B:PLSO.0000047751.25915.77

Ghadiri Khanaposhtani M, Kaboli M, Karami M et al (2012) Effect of habitat complexity on richness, abundance and distributional pattern of forest birds. Environ Manage 50:296-303

Gradel A, Ammer C, Ganbaatar B et al (2017) On the effect of thinning on tree growth and stand structure of white birch (Betula platyphylla Sukaczev) and siberian larch (Larix sibirica Ledeb) in Mongolia. Forests 8:105

Gustafsson L, Baker SC, Bauhus J et al (2012) Retention forestry to maintain multifunctional forests: a world perspective. Bioscience 62:633-645

Gustafsson L, Bauhus J, Asbeck T et al (2019) Retention as an integrated biodiversity conservation approach for continuous-cover forestry in Europe. Ambio 49:85-97

Heikkinen RK, Luoto M, Virkkala R et al (2004) Effects of habitat cover, landscape structure and spatial variables on the abundance of birds in an agricultural-forest mosaic. J Appl Ecol 41:824-835

Hurmekoski E, Hetemäki L, Linden M (2015) Factors affecting sawnwood consumption in Europe. Forest Policy and Economics 50:236-248. http://www.sciencedirect.com/science/article/pii/ S1389934114001397

Johann K DESER-Norm (1993) Normen der Sektion Ertragskunde im Deutschen Verband Forstlicher Forschungsanstalten zur Aufbereitung von waldwirtschaftlichen Dauerversuchen. Berichte der Jahrestagung des Deutschen Verbandes Forstlicher Sektion Ertragskunde in Unterreichenbach-Kapfenhardt: 96-104

Knoke T (2012) The economics of continuous cover forestry. In: Pukkala T (ed) Continuous cover forestry, 2nd edn. Springer, Dordrecht, London, pp 167-193

Kuuluvainen T, Tahvonen O, Aakala T (2012) Even-aged and unevenaged forest management in boreal Fennoscandia. Rev Ambio 41:720-737

Laudon H, Sponseller RA, Lucas RW et al (2011) Consequences of More Intensive Forestry for the Sustainable Management of Forest Soils and Waters. https://pdfs.semanticscholar.org/9768/796ce 2c2f6d74db6f06ad94caeb4408b110c.pdf

Leimgruber P, McShea WJ, Schnell GD (2002) Effects of scale and logging on landscape structure in a forest mosaic. Environ Monit Assess 74:141-166

Liang J, Buongiorno J, Monserud RA et al (2007) Effects of diversity of tree species and size on forest basal area growth, recruitment, and mortality. For Ecol Manage 243:116-127

Liang J, Crowther TW, Picard N et al (2016) Positive biodiversityproductivity relationship predominant in global forests. Science 354:aaf8957. http://science.sciencemag.org/content/ sci/354/6309/aaf8957.full.pdf

Lindenmayer DB, Margules CR, Botkin DB (2000) Indicators of biodiversity for ecologically sustainable forest management. Conserv Biol 14:941-950

Lutz JA, Larson AJ, Freund JA et al (2013) The importance of largediameter trees to forest structural heterogeneity. PLoS ONE 8:e82784

MacArthur RH, MacArthur JW (1961) On bird species diversity. Ecology 42:594-598

Mainwaring DB, Maguire DA (2004) The effect of local stand structure on growth and growth efficiency in heterogeneous stands of ponderosa pine and lodgepole pine in central Oregon. Can J For Res 34:2217-2229

Manning P, van der Plas F, Soliveres S et al (2018) Redefining ecosystem multifunctionality. Nat Ecol Evolut 2:427-436 
Marques S, Marto M, Bushenkov V et al (2017) Addressing wildfire risk in forest management planning with multiple criteria decision making methods. Sustainability 9:298

Mason WL (2002) Are irregular stands more windfirm? Forestry 75:347-355

Mensah S, Du Toit B, Seifert T (2018) Diversity-biomass relationship across forest layers: implications for niche complementarity and selection effects. Oecologia 187:783-795. https://doi. org/10.1007/s00442-018-4144-0

Mensah S, Salako KV, Assogbadjo A et al (2020) Functional trait diversity is a stronger predictor of multifunctionality than dominance: evidence from an Afromontane forest in South Africa. Ecol Ind 115:106415

Mestre L, Toro-Manríquez M, Soler R et al (2017) The influence of canopy-layer composition on understory plant diversity in southern temperate forests. For Ecosyst 4:189

Naeem S, Duffy JE, Zavaleta E (2012) The functions of biological diversity in an age of extinction. Science 336:1401-1406

Nascimbene J, Marini L, Motta R et al (2009) Influence of tree age, tree size and crown structure on lichen communities in mature Alpine spruce forests. Biodivers Conserv 18:1509-1522. https ://doi.org/10.1007/s10531-008-9537-7

Nolet P, Kneeshaw D, Messier C et al (2018) Comparing the effects of even- and uneven-aged silviculture on ecological diversity and processes: a review. Ecol and Evolut 8:1217-1226

Nordström E-M, Holmström H, Öhman K (2013) Evaluating continuous cover forestry based on the forest owner's objectives by combining scenario analysis and multiple criteria decision analysis. Silva Fenn 47:1-22

Nyland RD (2003) Even- to uneven-aged: the challenges of conversion. Forest Ecology and Management 172:291-300. http://www.scien cedirect.com/science/article/pii/S0378112701007976

O’Brien M, Bringezu S (2018) European Timber Consumption: Developing a Method to Account for Timber Flows and the EU's Global Forest Footprint. Ecological Economics 147:322-332. http://www.sciencedirect.com/science/article/pii/S092180091 7303440

O'Hara KL, Ramage BS (2013) Silviculture in an uncertain world: utilizing multi-aged management systems to integrate disturbance. Ann For Sci 86:401-410

Paquette A, Messier C (2011) The effect of biodiversity on tree productivity from temperate to boreal forests. Glob Ecol Biogeogr 20:170-180

Pohjanmies T, Triviño M, Le Tortorec E et al (2017) Impacts of forestry on boreal forests: an ecosystem services perspective. Ambio 46:743-755. https://doi.org/10.1007/s13280-017-0919-5

Pommerening A (2002) Approaches to quantifying forest structures. Forestry 75:305-324

Pommerening A (2006) Transformation to continuous cover forestry in a changing environment. For Ecol Manage 224:227-228

Pommerening A, Murphy ST (2004) A review of the history, definitions and methods of continuous cover forestry with special attention to afforestation and restocking. Forestry 77:27-44

Poschenrieder W, Biber P, Pretzsch H (2018) An inventory-based regeneration biomass model to initialize landscape scale simulation scenarios. Forests 9:212

Pretzsch H (1992) Konzeption und Konstruktion von Wuchsmodellen für Rein- und Mischbestände. [Concept and construction of growth modelsfor pure and mixed stands]. In: Forstliche Forschungsberichte München (115)

Pretzsch H (1996) Zum Einfluß waldbaulicher Maßnahmen auf die räumliche Bestandesstruktur Simulationsstudie über FichtenBuchen-Mischbestände in Bayern. In: Müller-Starck G, Ammer $\mathrm{C}$ (eds) Biodiversität und nachhaltige Forstwirtschaft Tagung des Forums Genetik - Wald - Forstwirtschaft Oktober 1995, 1st edn. Ecomed, Landsberg
Pretzsch H (2001) Modellierung des Waldwachstums Mit 10 Tabellen. Parey, Berlin

Pretzsch H (2009) Forest dynamics. Springer-Verlag, Berlin Heidelberg, Berlin, Heidelberg, Growth and Yield. From Measurement to Model

Pretzsch H, Biber P, Durský J et al (2006) The individual-tree-based stand simulator SILVA. In: Hasenauer H (ed) Sustainable forest management. Growth models for Europe, Springer, Berlin, London, pp 78-84

Pretzsch H, Biber P, Ďurský J (2002) The single tree-based stand simulator SILVA: construction, application and evaluation. For Ecol Manage 162:3-21

Pretzsch H, Grote R, Reineking B et al (2007) Models for forest ecosystem management: a European perspective. Ann Bot 101:1065-1087

Puettmann KJ, Wilson SM, Baker SC et al (2015) Silvicultural alternatives to conventional even-aged forest management - what limits global adoption? For Ecosyst 2:611

Pukkala T, Lähde E, Laiho O et al (2011) A multifunctional comparison of even-aged and uneven-aged forest management in a boreal region. Can J For Res 41:851-862

Qin K, Li J, Yang X (2015) Trade-off and synergy among ecosystem services in the Guanzhong-Tianshui economic region of China. Int J Environ Res Publ Health 12:14094-14113

R Core Team (2018) R: a language and environment for statistical computing. R Foundation for Statistical Computing, Vienna

Ranius T, Ekvall H, Jonsson M et al (2005) Cost-efficiency of measures to increase the amount of coarse woody debris in managed Norway spruce forests. For Ecol Manage 206:119-133

Reid WV (2005) Ecosystems and human well-being Synthesis; a report of the millennium ecosystem assessment. Island Press, Washington

Reineke LH (1933) Perfecting a stand-density index for even-aged forests. J Agric Res 46:627-638

Saab V (1999) Importance of spatial scale to habitat use by breeding birds in Riparian forests: a hierarchical analysis. Ecol Appl 9:135

Sabatini FM, Burrascano S, Lombardi F et al (2015) An index of structural complexity for Apennine beech forests. iForest 8:314-323

Salek L, Sivacioğlu A (2018) Forests for future - multifunctional forests. IJPSS 24:1-9

Schall P, Gossner MM, Heinrichs S et al (2018a) In beech forest landscapes composed of different management systems biodiversity increases with the share of even-aged forests. In: Proceedings of the 5th European Congress of Conservation Biology. Jyvaskyla University Open Science Centre, Jyväskylä

Schall P, Gossner MM, Heinrichs S et al (2018) The impact of evenaged and uneven-aged forest management on regional biodiversity of multiple taxa in European beech forests. J Appl Ecol 109:17495

Schmithüsen F (2008) Multifunctional forestry practices as a land use strategy to meet increasing private and public demands in modern societies. J For Sci 53:290-298

Schwaiger F, Poschenrieder W, Biber P et al (2018) Species mixing regulation with respect to forest ecosystem service provision. Forests 9:632

Schwaiger F, Poschenrieder W, Biber P et al (2019) Ecosystem service trade-offs for adaptive forest management. Ecosystem Services 39:100993. http://www.sciencedirect.com/science/article/pii/ S2212041619300828

Schwaiger F, Poschenrieder W, Rötzer T et al (2018b) Groundwater recharge algorithm for forest management models. Ecological Modelling 385:154-164. http://www.sciencedirect.com/science/ article/pii/S0304380018302412

Sefidi K (2018) Quantitative evaluation of habitat and dead tree abundance in the oriental beech (Fagus orientalis Lipsky) stands, case study from the Siahkal Forests. Iranian Journal of Forest 
and Poplar Research 26:331-343. http://ijfpr.areeo.ac.ir/artic le_117737_0edee1997b58eecf175baca2548e9c0a.pdf

Sikkema R, Dallemand JF, Matos CT et al (2017) How can the ambitious goals for the EU's future bioeconomy be supported by sustainable and efficient wood sourcing practices? Scand J For Res 32:551-558

Simonsson P, Gustafsson L, Östlund L (2015) Retention forestry in Sweden: driving forces, debate and implementation 1968-2003. Scand J For Res 30:154-173

Simonsson P, Östlund L, Gustafsson L (2016) Conservation values of certified-driven voluntary forest set-asides. Forest Ecology and Management 375:249-258. http://www.sciencedirect.com/scien ce/article/pii/S0378112716302869

Soares AAV, Leite HG, Souza AL et al (2016) Increasing stand structural heterogeneity reduces productivity in Brazilian Eucalyptus monoclonal stands. For Ecol Manage 373:26-32

Stein A, Gerstner K, Kreft H (2014) Environmental heterogeneity as a universal driver of species richness across taxa, biomes and spatial scales. Ecol Lett 17:866-880

Sterba H, Zingg A (2001) Target diameter harvesting — a strategy to convert even-aged forests. Forest Ecology and Management 151:95-105. http://www.sciencedirect.com/science/article/pii/ S0378112700007003

Terraube J, Archaux F, Deconchat M et al (2016) Forest edges have high conservation value for bird communities in mosaic landscapes. Ecol and Evolut 6:5178-5189

Tews J, Brose U, Grimm V et al (2004) Animal species diversity driven by habitat heterogeneity/diversity: the importance of keystone structures. J Biogeogr 31:79-92

Toraño Caicoya A, Biber P, Poschenrieder W et al (2018) Forestry projections for species diversity-oriented management: an example from Central Europe. Ecol Process 7:357
Uhl E, Biber P, Ulbricht M et al (2015) Analysing the effect of stand density and site conditions on structure and growth of oak species using Nelder trials along an environmental gradient: experimental design, evaluation methods, and results. Forest Ecosystems 2:17. https://forestecosyst.springeropen.com/track/pdf/https ://doi.org/10.1186/s40663-015-0041-8?site=forestecosyst.sprin geropen.com

van der Plas F, Manning P, Soliveres S et al (2016) Biotic homogenization can decrease landscape-scale forest multifunctionality. PNAS 113:3557-3562. https://www.pnas.org/content/ pnas/113/13/3557.full.pdf

von Gadow K, Nagel J, Saborowski J (2002) Continuous cover forestry. Springer, Netherlands, Dordrecht, Assessment, Analysis, Scenarios

Wood SN (2017) Generalized Additive Models. Chapman and Hall/ CRC

Yang Z, Liu X, Zhou M et al (2015) The effect of environmental heterogeneity on species richness depends on community position along the environmental gradient. Scientific reports 5:15723. https://www.nature.com/articles/srep15723.pdf

Zeller L, Liang J, Pretzsch H (2018) Tree species richness enhances stand productivity while stand structure can have opposite effects, based on forest inventory data from Germany and the United States of America. For Ecosyst 5:4

Zeller L, Pretzsch H (2019) Effect of forest structure on stand productivity in Central European forests depends on developmental stage and tree species diversity. For Ecol Manage 434:193-204

Zhang Y, Ma K, Anand M et al (2015) Scale dependence of the beta diversity-scale relationship. Commun Ecol 16:39-47

Publisher's Note Springer Nature remains neutral with regard to jurisdictional claims in published maps and institutional affiliations. 